\title{
Maintenance and growth requirements for nitrogen, lysine and methionine and their utilisation efficiencies in juvenile black tiger shrimp, Penaeus monodon, using a factorial approach
}

\author{
Lenaïg Richard ${ }^{1,2}$, Pierre-Philippe Blanc ${ }^{2}$, Vincent Rigolet ${ }^{2}$, Sadasivam J. Kaushik ${ }^{1}$ and Inge Geurden ${ }^{1 *}$ \\ ${ }^{1}$ INRA, UMR 1067 Nutrition, Aquaculture and Genomics, F-64310 St-Pée-sur-Nivelle, France \\ ${ }^{2}$ AQUALMA, BP 93 Immeuble SCIM, 4 rue Galliéni, Mahajanga 401, Madagascar \\ (Received 18 June 2009 - Revised 28 September 2009 - Accepted 12 October 2009 - First published online 30 November 2009)
}

We used a factorial approach to distinguish maintenance from growth requirements for protein, lysine and methionine in the black tiger shrimp, Penaeus monodon. Juvenile P. monodon (initial weight $2.4 \mathrm{~g}$ ) were fed during 6 weeks one of ten semi-purified diets based on casein and purified amino acids (AA) as $\mathrm{N}$ source. The diets contained four levels of crude protein (CP, from 5 to $54 \% \mathrm{DM}$ diet) with two levels (\% $\mathrm{CP}$ ) of lysine or methionine (normal or $30 \%$ deficient). Requirements were determined using linear and non-linear regression models. We could thus obtain the first ever data on maintenance ( $\mathrm{N}$ equilibrium) requirements for $\mathrm{CP}$ and $\mathrm{AA}$ in $P$. monodon. $\mathrm{CP}$ requirements for maintenance (4.5 g/kg body weight $(\mathrm{BW})$ per d) represented approximately $19 \%$ of the $\mathrm{CP}$ requirement for maximal $\mathrm{N}$ gain $(23.9 \mathrm{~g} / \mathrm{kg} \mathrm{BW}$ per d). The marginal efficiency of utilisation reached a maximum of $38 \%$ for $\mathrm{N}, 0.77$ for lysine and 1.62 for methionine using $\mathrm{N}$ gain as response. Lysine requirements were $0 \cdot 20 \mathrm{~g} / \mathrm{kg} \mathrm{BW}$ per $\mathrm{d}$ for $\mathrm{N}$ maintenance and $1.40 \mathrm{~g} / \mathrm{kg} \mathrm{BW}$ per $\mathrm{d}$ for maximal N gain. Methionine requirements were $0 \cdot 11 \mathrm{~g} / \mathrm{kg} \mathrm{BW}$ per d for N maintenance and $0.70 \mathrm{~g} / \mathrm{kg} \mathrm{BW}$ per $\mathrm{d}$ for maximal $\mathrm{N}$ gain. The lysine $(5.8 \%)$ and methionine $(2.9 \%)$ requirements for maximal $\mathrm{N}$ gain, expressed as percentage of protein requirement, agree with literature data using a dose-response technique with smaller $P$. monodon. The observed interaction between dietary $\mathrm{CP}$ and methionine for $\mathrm{N}$ gain demonstrates that requirements for indispensable $\mathrm{AA}$ (expressed as \% $\mathrm{CP}$ ) cannot be evaluated separately from CP requirements.

Crustaceans: Protein requirement: Indispensable amino acids: Logistic model: Marginal utilisation efficiency

The black tiger shrimp (Penaeus monodon) is the second most cultured crustacean species worldwide ${ }^{(1)}$. Due to the importance of protein for shrimp growth, its high cost in formulated feeds and the environmental implications of $\mathrm{N}$ losses, it is essential to gain a better understanding of $\mathrm{N}$ requirements and $\mathrm{N}$ utilisation in $P$. monodon. Available data on crude protein requirements $(\mathrm{CP}, \% \mathrm{DM}$ diet $)$ of $P$. monodon show a large degree of variability, i.e. from $36-40 \%{ }^{(2)}$ up to $50 \%{ }^{(3)}$. Several factors, e.g. differences in protein source, dietary energy level, life stage, rearing conditions and, in particular, differences in feed intake (FI), can explain some of this variation ${ }^{(4)}$. The confounding effect of FI on dietary protein requirement estimates has also been illustrated with the pacific white shrimp, Litopenaeus vannamei ${ }^{(5,6)}$. The latter authors ${ }^{(6)}$ demonstrated that maximum weight gain could be obtained by a wide range of dietary $\mathrm{CP}$ levels (30-40\% DM diet) at different feed allowances (50, 75 and $100 \%$ of typical daily intakes), underlining the importance of expressing protein requirements on absolute basis rather than as a percentage of the diet. The use of the factorial approach, which allows the distinction between maintenance and growth for estimating protein requirements, has been initially developed for terrestrial animals ${ }^{(7,8)}$ and has also been applied for teleost fish ${ }^{(9-11)}$. For shrimp, data on protein requirements using the factorial approach have been documented for two marine species: L. vannamei ${ }^{(5)}$ and the Kuruma prawn Marsupenaeus japonicus ${ }^{(12)}$, reported as having more carnivorous feeding habits than L. vannamei, and for the freshwater prawn Macrobrachium rosenbergii, with herbivorousomnivorous feeding habits ${ }^{(13)}$. For P. monodon, so far, no studies applied the factorial approach in order to distinguish maintenance from growth protein requirements.

In studies on amino acid (AA) requirements, the dietary AA profile is mostly based on either shrimp whole body or tail muscle composition as the reference ${ }^{(14,15)}$. With the increasing use of plant-based proteins in shrimp feed as an alternative to marine protein sources (fish, shrimp or squid meal), lysine and methionine will be the first two limiting indispensable AA $(\text { IAA })^{(16)}$. Data on the requirements of $P$. monodon for lysine and methionine are limited to the studies of Millamena et al. ${ }^{(14,17)}$, who estimated requirements of post-larval $P$. monodon based on growth response using diets with fixed CP level (37 or $40 \%$ ) and different levels of lysine and methionine. The dose-response method has been criticised

Abbreviations: AA, amino acid; BLM, broken line model; BW, body weight; CP, crude protein; FE, feed efficiency; FI, feed intake; HP, high protein;

IAA, indispensable AA; LP, low protein; MP, medium protein; NP, non-protein.

* Corresponding author: Inge Geurden, fax +33 559545152, email geurden@st-pee.inra.fr 
since the IAA balance differs in each of the test diets, in contrast to the 'diet dilution' technique that is based on a 'summit' diet with high-protein level being diluted with a protein-free or low-protein diet of similar IAA profile ${ }^{(18)}$. Furthermore, a combination of both methods ${ }^{(7,19)}$, using diets in which the protein level is 'diluted' by non-protein (NP) nutrients while creating an IAA deficiency at each of the tested protein levels, has been used in studies with fish $^{(10,11,20)}$. This provides simultaneous estimations of protein and IAA requirements in a single study, and enables to analyse the relationship between the level of IAA and that of total CP. In studies on fish, as in other animals, some controversy exists on potential interactions between levels of IAA and CP on for instance the utilisation efficiency of the first limiting IAA, possibly leading to wrong estimations of requirements ${ }^{(20,21)}$. Another point, not examined in shrimp, concerns the validity of applying the ideal protein pattern in high-protein diets, i.e. the question whether the different IAA are always required as a constant proportion of crude protein or not. This point has received a lot of attention in broilers ${ }^{(22,23)}$ and is of practical relevance for diets in which poor quality protein sources are included at higher than normal levels to provide a minimal level of IAA in the diet (\% diet), resulting in imbalanced dietary AA profiles (\% $\mathrm{CP})$.

The aim of the present study was to determine, within a single feeding trial, the requirements for protein and for two
IAA, lysine and methionine, for maintenance ( $\mathrm{N}$ equilibrium) and maximal body protein deposition of juvenile $P$. monodon and to study the possible relationship between the limiting IAA and dietary CP supply. Different mathematical models were used to determine the requirements, giving consideration to the basic assumptions behind and to obtain original data on efficiency of $\mathrm{N}$ and AA utilisation in shrimp.

\section{Materials and methods}

\section{Experimental diets}

Ten semi-purified diets were formulated with four different levels of crude protein (CP) and two levels of lysine or methionine (adequate or $30 \%$ deficient). The $\mathrm{N}$ source was casein and a blend of crystalline AA in a 55:45 ratio (casein:AA blend; Tables 1 and 2). NP, low-protein (LP), medium-protein (MP) and high-protein (HP) diets were formulated to supply 0 , $1 \cdot 6,4.8$ and $8.1 \% \mathrm{~N}$, respectively. Fish protein soluble concentrate $(20 \mathrm{~g} / \mathrm{kg}$ diet $)$ and an attractant mix (glucosamine, taurine, betaine, glycine and alanine) (15 g/kg diet) were included in all diets in order to improve palatability, which provided an additional $\mathrm{N}$ source in all diets, including in the 'protein-free NP diet' ( $0.8 \% \mathrm{~N}$, Table 1$)$. Gelatinised starch levels compensated for varying CP levels. The four diets, NP, LP, MP and HP, had a similar AA (indispensable and non-indispensable)

Table 1. Formulation and analysed composition of the ten experimental semi-purified diets fed to Penaeus monodon juveniles for 6 weeks

\begin{tabular}{|c|c|c|c|c|c|c|c|c|c|c|}
\hline \multirow[b]{2}{*}{ Ingredients ( $\mathrm{g} / \mathrm{kg}$ diet) } & \multicolumn{10}{|c|}{ Diets } \\
\hline & NP & LP & LPM & LPL & MP & MPM & MPL & $\mathrm{HP}$ & HPM & HPL \\
\hline Casein* & 0 & 62 & 62 & 62 & 186 & 186 & 186 & 310 & 310 & 310 \\
\hline Amino acid mix $†$ & 0 & 45 & 45 & 45 & 135 & 135 & 135 & 225 & 225 & 225 \\
\hline Cholesterol $\ddagger$ & 20 & 20 & 20 & 20 & 20 & 20 & 20 & 20 & 20 & 20 \\
\hline Soyabean lecithin§ & 20 & 20 & 20 & 20 & 20 & 20 & 20 & 20 & 20 & 20 \\
\hline Fish oilł & 60 & 60 & 60 & 60 & 60 & 60 & 60 & 60 & 60 & 60 \\
\hline Sodium alginate§ & 50 & 50 & 50 & 50 & 50 & 50 & 50 & 50 & 50 & 50 \\
\hline Mineral mix\| & 50 & 50 & 50 & 50 & 50 & 50 & 50 & 50 & 50 & 50 \\
\hline Vitamin mix & 50 & 50 & 50 & 50 & 50 & 50 & 50 & 50 & 50 & 50 \\
\hline Agar $^{\star}$ & 15 & 15 & 15 & 15 & 15 & 15 & 15 & 15 & 15 & 15 \\
\hline Cellulose & 20 & 20 & 20 & 20 & 20 & 20 & 20 & 20 & 20 & 20 \\
\hline Fish protein-soluble concentrate§ & 20 & 20 & 20 & 20 & 20 & 20 & 20 & 20 & 20 & 20 \\
\hline Gelatinised maize starch** & 680 & 573 & 573 & 573 & 359 & 358 & 359 & 144 & 144 & 144 \\
\hline Attractant mix $† \dagger$ & 15 & 15 & 15 & 15 & 15 & 15 & 15 & 15 & 15 & 15 \\
\hline \multicolumn{11}{|l|}{ Analysed chemical composition } \\
\hline DM (\% diet) & $89 \cdot 6$ & $89 \cdot 3$ & $90 \cdot 6$ & $90 \cdot 4$ & $90 \cdot 6$ & $89 \cdot 8$ & 89.5 & $89 \cdot 0$ & $89 \cdot 2$ & $89 \cdot 1$ \\
\hline $\mathrm{N}(\% \mathrm{DM})$ & 0.82 & $2 \cdot 31$ & 2.71 & $2 \cdot 31$ & $5 \cdot 45$ & $5 \cdot 44$ & $5 \cdot 28$ & $8 \cdot 52$ & 8.65 & $8 \cdot 62$ \\
\hline Crude protein $(\mathrm{N} \times 6.25, \% \mathrm{DM})$ & $5 \cdot 1$ & $14 \cdot 4$ & $16 \cdot 9$ & $14 \cdot 4$ & $34 \cdot 1$ & $34 \cdot 0$ & $33 \cdot 0$ & $53 \cdot 2$ & $54 \cdot 1$ & $53 \cdot 9$ \\
\hline Lys (\% DM) & 0.18 & 0.91 & 1.04 & 0.66 & $2 \cdot 35$ & $2 \cdot 39$ & 1.62 & $3 \cdot 63$ & 3.68 & $2 \cdot 56$ \\
\hline Met (\% DM) & 0.10 & 0.44 & 0.38 & 0.47 & 0.96 & 0.69 & 0.99 & 1.54 & $1 \cdot 12$ & 1.60 \\
\hline Crude lipid (\% DM) & $6 \cdot 8$ & $6 \cdot 8$ & $7 \cdot 0$ & $7 \cdot 4$ & $7 \cdot 8$ & $6 \cdot 9$ & $7 \cdot 7$ & $7 \cdot 5$ & $7 \cdot 5$ & $7 \cdot 7$ \\
\hline Ash (\% DM) & $5 \cdot 7$ & $5 \cdot 7$ & $5 \cdot 8$ & $5 \cdot 7$ & $6 \cdot 0$ & $6 \cdot 0$ & $6 \cdot 0$ & $5 \cdot 9$ & $6 \cdot 0$ & $6 \cdot 1$ \\
\hline Gross energy (kJ/g DM) & $18 \cdot 6$ & $19 \cdot 0$ & $19 \cdot 3$ & $19 \cdot 2$ & $20 \cdot 2$ & $20 \cdot 1$ & $19 \cdot 6$ & $21 \cdot 3$ & $21 \cdot 0$ & $21 \cdot 0$ \\
\hline
\end{tabular}

NP, non-protein; LP, low protein; LPM, methionine-deficient low-protein diets; LPL, lysine-deficient low-protein diets; MP, medium protein; MPM, methionine-deficientmediumprotein diets; MPL, lysine-deficient medium-protein diets; HP, high protein; HPM, methionine-deficient high-protein diets; HPL, lysine-deficient high-protein diets.

${ }^{*}$ Acros France; $95 \%$ stabilised cholesterol; $98 \%$ glycine; $98 \%$ D-glucosamine; HCl; agar powder; pure casein (CAS 9000-71-9).

† Eurolysine and Acros (see Table 2 for details).

‡Louis François (St Maur, France).

§ Sopropêche (Lorient, France).

II Roquette (Lestrem, France).

I Contained glucosamine, taurine, betaine, glycine and alanine as 5:3:3:2:2

${ }^{*}$ Supplied the following (to provide $\mathrm{g} / \mathrm{kg}$ mixture): magnesium oxide, 124; calcium carbonate, $215 ; \mathrm{KCl}, 90 ; \mathrm{NaCl}, 40 ; \mathrm{KI}, 40 \mathrm{mg} ; \mathrm{copper}$ sulphate, 3 ; cobalt sulphate, $20 \mathrm{mg}$; ferric sulphate, 20; manganese sulphate, $3 ; \mathrm{ZnSO}_{4}, 4$; dibasic calcium phosphate, 500; NAF, 1.

†† Supplied the following (to provide $\mathrm{g} / \mathrm{kg}$ mixture): retinyl acetate $(A), 0.172,1$; thiamin $\left(B_{1}\right), 0.1$; riboflavin $\left(B_{2} ; 80 \%\right)$, $0.5 ;$ nicotinic acid $\left(B_{3}\right)$, 1 ; calcium pantothenate $\left(B_{5}, 98 \%\right), 2$; pyridoxine $\left(B_{6}\right), 0.3$; inositol $\left(B_{7}\right), 30$; biotin $\left(B_{8}, 2 \%\right), 1$; folic acid $\left(B_{9}\right), 0.1$; vitamin $B_{12}(1 \mathrm{~g} / \mathrm{kg}), 1 ;$ ascorbic acid $(C, 35 \%), 14 \cdot 29 ;$ cholecalciferol $\left(D_{3}\right), 0.006$; tocopheryl acetate $(\mathrm{E}), 3.7$; menadione $\left(\mathrm{K}_{3}, 50 \%\right), 2$; choline chloride $(60 \%), 167$. 
Table 2. Formulation of the amino acids blend added to the semi-purified casein-based diets (g/kg diet)

\begin{tabular}{|c|c|c|c|c|c|c|c|c|c|}
\hline \multirow[b]{2}{*}{ Amino acids } & \multicolumn{9}{|c|}{ Diets } \\
\hline & LP & LPM & LPL & MP & MPM & MPL & $\mathrm{HP}$ & HPM & HPL \\
\hline $\operatorname{Arg}^{*}$ & $7 \cdot 3$ & $7 \cdot 3$ & $7 \cdot 3$ & $21 \cdot 8$ & $21 \cdot 8$ & $21 \cdot 8$ & $36 \cdot 3$ & $36 \cdot 3$ & $36 \cdot 3$ \\
\hline Hist & 0.4 & 0.4 & 0.4 & $1 \cdot 1$ & $1 \cdot 1$ & $1 \cdot 1$ & $1 \cdot 8$ & $1 \cdot 8$ & $1 \cdot 8$ \\
\hline lleł & $1 \cdot 0$ & 1.0 & $1 \cdot 0$ & $3 \cdot 1$ & $3 \cdot 1$ & $3 \cdot 1$ & $5 \cdot 1$ & $5 \cdot 1$ & $5 \cdot 1$ \\
\hline Leuł & $2 \cdot 1$ & $2 \cdot 1$ & $2 \cdot 1$ & $6 \cdot 4$ & $6 \cdot 4$ & 6.4 & $10 \cdot 7$ & $10 \cdot 7$ & $10 \cdot 7$ \\
\hline Lyst & 3.4 & 3.4 & 0.2 & $10 \cdot 3$ & $10 \cdot 3$ & 0.6 & $17 \cdot 2$ & $17 \cdot 2$ & 1.0 \\
\hline DL-Met† & 0.9 & 0.0 & 0.9 & $2 \cdot 8$ & 0.0 & $2 \cdot 8$ & $4 \cdot 7$ & 0.0 & 4.7 \\
\hline Phe‡ & $1 \cdot 2$ & $1 \cdot 2$ & $1 \cdot 2$ & 3.6 & 3.6 & $3 \cdot 6$ & $6 \cdot 0$ & $6 \cdot 0$ & $6 \cdot 0$ \\
\hline Tyrł & 0.4 & 0.5 & 0.7 & $1 \cdot 3$ & 1.6 & $2 \cdot 0$ & $2 \cdot 1$ & 2.7 & $3 \cdot 3$ \\
\hline Trpł & 0.5 & 0.5 & 0.5 & 1.5 & 1.5 & 1.5 & 2.5 & 2.5 & 2.5 \\
\hline Valf & 0.7 & 0.7 & 0.7 & $2 \cdot 0$ & $2 \cdot 0$ & $2 \cdot 0$ & 3.4 & 3.4 & 3.4 \\
\hline Asp $\ddagger$ & $5 \cdot 8$ & $6 \cdot 1$ & 6.4 & $17 \cdot 3$ & $18 \cdot 2$ & $19 \cdot 1$ & $28 \cdot 8$ & $30 \cdot 3$ & 31.9 \\
\hline Thrł & 1.5 & 1.5 & 1.5 & $4 \cdot 4$ & $4 \cdot 4$ & 4.4 & $7 \cdot 3$ & $7 \cdot 3$ & $7 \cdot 3$ \\
\hline Ser‡ & 0.3 & 0.4 & 0.5 & 1.0 & $1 \cdot 3$ & 1.6 & $1 \cdot 6$ & $2 \cdot 1$ & $2 \cdot 7$ \\
\hline Gluł & $2 \cdot 8$ & $3 \cdot 2$ & $3 \cdot 8$ & $8 \cdot 4$ & $9 \cdot 7$ & $11 \cdot 3$ & $14 \cdot 0$ & $16 \cdot 2$ & $18 \cdot 8$ \\
\hline Proł & $5 \cdot 7$ & $5 \cdot 8$ & $6 \cdot 0$ & $17 \cdot 0$ & $17 \cdot 5$ & $18 \cdot 0$ & $28 \cdot 3$ & $29 \cdot 1$ & $30 \cdot 0$ \\
\hline Gly* & $6 \cdot 3$ & $6 \cdot 5$ & $6 \cdot 7$ & $18 \cdot 8$ & $19 \cdot 4$ & $20 \cdot 1$ & $31 \cdot 3$ & $32 \cdot 3$ & 33.5 \\
\hline Alał & 3.9 & $4 \cdot 1$ & $4 \cdot 3$ & $11 \cdot 8$ & $12 \cdot 3$ & $12 \cdot 8$ & $19 \cdot 6$ & 20.5 & 21.4 \\
\hline Cysł & 0.9 & 0.4 & 0.9 & $2 \cdot 6$ & $1 \cdot 3$ & $2 \cdot 8$ & $4 \cdot 3$ & $2 \cdot 1$ & $4 \cdot 7$ \\
\hline Total (g/kg diet) & $45 \cdot 0$ & $45 \cdot 1$ & $45 \cdot 0$ & $135 \cdot 0$ & $135 \cdot 3$ & $135 \cdot 0$ & $225 \cdot 0$ & 225.5 & $225 \cdot 0$ \\
\hline
\end{tabular}

profile (\% CP; Table 3), which was based on the AA composition of shrimp whole body ('ideal AA profile', compiled from literature). The six other diets, lysine-deficient LP, methionine-deficient LP, lysine-deficient MP, methionine-deficient MP, lysine-deficient HP and methionine-deficient HP, were formulated to be $30 \%$ deficient in either lysine (L diets) or methionine (M diets) (Table 3). The AA deficiencies (relative to the AA profile of the adequate diets) were obtained by replacing the tested AA from the AA blend by non-IAA in order to keep diets isonitrogenous at each level of total $\mathrm{N}$ supply. The ratio of cystine:methionine was kept constant at approximately 0.3 in all diets so that the levels of cystine were proportionally lower in the methionine-deficient diets (Table 2). Each AA blend (Table 2) was coated with agar ${ }^{(24)}$ dissolved in warm water $\left(30^{\circ} \mathrm{C} ; \mathrm{pH} 5\right)$ before being mixed with the other ingredients. The experimental diets were manufactured by Institut National de la Recherche Agronomique at the experimental facility of Donzacq (France). Ingredients such as casein, cholesterol, lecithin, sodium alginate, cellulose, fish protein-soluble concentrate, gelatinised starch

Table 3. Analysed amino acid composition of the ten experimental diets $(\mathrm{g} / 16 \mathrm{~g}$ nitrogen)

\begin{tabular}{|c|c|c|c|c|c|c|c|c|c|c|}
\hline & \multicolumn{10}{|c|}{ Diets } \\
\hline & NP & LP & LPM & LPL & MP & MPM & MPL & $\mathrm{HP}$ & HPM & HPL \\
\hline Arg & 3.7 & 8.0 & $8 \cdot 1$ & 8.0 & 8.4 & 8.0 & 8.3 & 7.9 & $7 \cdot 7$ & 7.8 \\
\hline $\mathrm{His}$ & 0.9 & 1.6 & 1.6 & 1.6 & 1.8 & 1.9 & 1.8 & 1.8 & $1 \cdot 8$ & 1.8 \\
\hline Ile & $2 \cdot 2$ & 3.5 & $3 \cdot 6$ & 3.3 & 3.7 & 3.8 & 3.8 & 3.7 & $3 \cdot 8$ & 3.7 \\
\hline Leu & 4.4 & $7 \cdot 2$ & $7 \cdot 3$ & 7.4 & 7.7 & $7 \cdot 8$ & $7 \cdot 7$ & 7.9 & 7.9 & 7.9 \\
\hline Lys & 3.5 & $6 \cdot 3$ & $6 \cdot 1$ & 4.6 & 6.9 & $7 \cdot 0$ & 4.9 & 6.8 & $6 \cdot 8$ & 4.8 \\
\hline Met & $2 \cdot 0$ & 3.0 & $2 \cdot 2$ & $3 \cdot 3$ & $2 \cdot 8$ & $2 \cdot 0$ & 3.0 & 2.9 & $2 \cdot 1$ & 3.0 \\
\hline Phe & $2 \cdot 6$ & 3.9 & $3 \cdot 8$ & 4.2 & 4.2 & $4 \cdot 3$ & 4.3 & 4.2 & 4.1 & 4.6 \\
\hline Tyr & 1.5 & $2 \cdot 7$ & $2 \cdot 7$ & $2 \cdot 7$ & 3.2 & 3.3 & 3.3 & 3.4 & 3.4 & 3.4 \\
\hline Val & $2 \cdot 6$ & 4.2 & 4.3 & $4 \cdot 1$ & 4.5 & 4.7 & 4.6 & 4.4 & 4.4 & 4.4 \\
\hline Asp & $5 \cdot 7$ & 9.8 & 9.8 & $10 \cdot 0$ & $10 \cdot 0$ & 9.9 & $10 \cdot 2$ & 9.5 & 9.4 & 9.7 \\
\hline Thr & $2 \cdot 4$ & 3.8 & 3.9 & 3.7 & 3.9 & 3.9 & 3.9 & 3.8 & 3.8 & 3.7 \\
\hline Ser & 2.4 & 3.4 & 3.4 & 3.3 & 3.5 & 3.7 & 3.6 & 3.5 & 3.7 & 3.5 \\
\hline Glu & 8.3 & 14.6 & $14 \cdot 8$ & 14.9 & 14.7 & $15 \cdot 0$ & $15 \cdot 0$ & $15 \cdot 6$ & $16 \cdot 0$ & $16 \cdot 0$ \\
\hline Pro & 4.6 & $10 \cdot 6$ & $10 \cdot 7$ & 10.5 & 11 & $11 \cdot 1$ & $11 \cdot 3$ & 10.9 & 10.9 & $10 \cdot 9$ \\
\hline Gly & 9.4 & 8.7 & 8.5 & $8 \cdot 7$ & 6.6 & $6 \cdot 0$ & $6 \cdot 1$ & $7 \cdot 0$ & $6 \cdot 9$ & $7 \cdot 0$ \\
\hline Ala & 7.4 & $7 \cdot 2$ & $7 \cdot 1$ & 7.4 & 6.0 & $5 \cdot 7$ & $6 \cdot 0$ & $5 \cdot 7$ & 5.6 & 5.9 \\
\hline Cys & 0.7 & 0.9 & 0.7 & $1 \cdot 1$ & 0.9 & 0.6 & 1.0 & 0.8 & 0.6 & 0.9 \\
\hline
\end{tabular}

NP, non-protein; LP, low protein; LPM, methionine-deficient low-protein diet; LPL, lysine-deficient low-protein diet; MP, medium protein; MPM, methionine-deficient medium-protein diet; MPL, lysine-deficient medium-protein diet; HP, high protein; HPM, methionine-deficient high-protein diet; HPL, lysine-deficient high-protein diet. 
and attractants were first mixed together and homogenised before adding the coated AA blend and the fish oil. After thorough mixing, feed was pelleted (meat grinder, $3 \mathrm{~mm}$ ), dried at $40^{\circ} \mathrm{C}$ and stored in sealed bags prior shipping to the experimental site in Madagascar, where it was stored at $4^{\circ} \mathrm{C}$.

\section{Experimental animals}

The feeding trial was undertaken at the hatchery facilities of Aqualma, Madagascar. Forty-three 150 litres fibreglass tanks $(80 \times 30.5$; diameter $\times$ height $)$ were used and stocked each with fifteen juvenile (85-d-old post-larvae) $P$. monodon (initial mean weight: $2.36 \mathrm{~g}$ (SE $0 \cdot 10)$ ), reared in earthen ponds for $66 \mathrm{~d}$ before the experiment. At the start of the study, juveniles were individually weighed and allocated to the respective tanks. During the $10 \mathrm{~d}$ of adaptation, all groups were fed MP diet at an initial ration level of $2 \%$ biomass per d. During the growth trial, which lasted 6 weeks, each of the ten experimental diets was distributed to four replicate groups allocated randomly. A commercial practical diet (CP: $46 \%$; crude fat: $7 \%$; Nutrima, La Réunion, Madagascar) was included as a control with three replicates to follow overall performance.

Sea water was filtered through a $50 \mu$ sand filtration system before distribution into the tank. The minimum water exchange was $40 \%$ of the tank volume and was done every morning before the first feeding. Temperature, $\mathrm{pH}$ and oxygen concentration of the water were measured twice daily (morning at 04.00 and afternoon at 17.00 hours). Salinity was recorded daily at 16.00 hours. Analyses for nitrate-N, nitrite- $\mathrm{N}$ and ammonia- $\mathrm{N}$ in the water in all the forty-three tanks were made every week using commercial kits (Nitraver ${ }^{\circledR} 5$ Nitrate, Nitriver ${ }^{\circledR} 3$ Nitrite and salicylate kit; Hach, Loveland, CO, USA). Average $\mathrm{pH}$, oxygen concentration, temperature and salinity of the water were 8.0 (SD $0 \cdot 1$ ), $5 \cdot 7(\mathrm{sD} 0.5) \mathrm{mg} / \mathrm{l}, 30 \cdot 1(\mathrm{SD} 1.6)^{\circ} \mathrm{C}$ and 30.8 (SD 1.8) ppt, respectively. Total ammonia nitrogen, nitrate $\left(\mathrm{N}-\mathrm{NO}_{3}\right)$ and nitrite $\left(\mathrm{N}_{-} \mathrm{NO}_{2}\right)$ were $0.17(\mathrm{SD} 0.26), 0.88(\mathrm{SD} 0.47)$ and 0.15 (SD 0.22) $\mathrm{mg} / \mathrm{l}$, respectively.

Special care was taken to assess actual feed consumption and to adapt feed distributions to the demands of each group. Feed distributions were done four times daily (08.00; $13.00 ; 18.00 ; 23.00$ hours). At each distribution, feed was deposited into two small circular trays $(20 \mathrm{~cm}$ diameter placed inside the tank. Two hours after each feed distribution, the trays were checked and leftovers were counted, collected in a box and stored at $-20^{\circ} \mathrm{C}$ until the next collecting time. A code was established to determine the amount of feed to be distributed at the next meal:

0 : all the feed was consumed, the next distribution increased by $30 \%$ more than the previous one;

1: less than three pellets remained in the tray, the next distribution was of equal amount;

2: more than three pellets remained in the tray, the next distribution was decreased by $30 \%$.

All feed leftovers were collected from each tray and pooled per tank on a weekly basis. DM content of each uneaten feed sample was determined by drying to a constant weight at $90^{\circ} \mathrm{C}$ for $48 \mathrm{~h}$. We could thus estimate actual FI for each tank on a weekly basis. N, lysine and methionine intakes were calculated from the total FI measured.
Biomass of each tank was measured every 2 weeks during the whole trial. Mortality was checked before and after each feeding period; dead animals were removed and weighed. Exuvia were removed from the tanks as soon as they were observed in order to avoid the animals to feed on them.

Performance calculations were as follows:

$$
\text { Survival rate }(\%)=\frac{100 \times \text { final number }}{\text { initial number }} \text {. }
$$

Total DM feed intake (total FI (gDM))

$=$ amount of feed distributed - amount of recovered feed.

Daily FI (gDM/kg body weight (BW) per d)

$$
=\frac{\text { total } \mathrm{FI}}{\text { average } \mathrm{BW} \times \text { average number } \times 42 \mathrm{~d}} .
$$

Specific growth rate $(\% / d)=\frac{100 \times\left(\ln \left(\mathrm{BW}_{\mathrm{F}}\right)-\ln \left(\mathrm{BW}_{\mathrm{I}}\right)\right)}{42 \mathrm{~d}}$

$$
\text { Feed efficiency }(\mathrm{FE})=\frac{B_{\mathrm{F}}-B_{\mathrm{I}}+B_{\mathrm{D}}}{\text { total FI }}
$$

$\mathrm{N}$ intake $(\mathrm{g} / \mathrm{kg} \mathrm{BW}$ per $\mathrm{d})=$ daily $\mathrm{FI} \times \% \mathrm{~N}$ content feed

$\mathrm{Ngain}(\mathrm{g} / \operatorname{kg~BW}$ perd $)=\frac{\left(N_{\text {ShrimpF }} \times \mathrm{BW}_{\mathrm{F}}\right)-\left(N_{\text {Shrimp }} \times \mathrm{BW}_{\mathrm{I}}\right)}{\text { average } \mathrm{BW} \times 42 \mathrm{~d}}$

$$
\text { Nretention }=\frac{\text { Ngain }}{\text { Nintake }} \times 100,
$$

where $\mathrm{BW}_{\mathrm{I}}, \mathrm{BW}_{\mathrm{F}}$, initial and final $\mathrm{BW}(\mathrm{g})$ and average $\mathrm{BW}$ $(\mathrm{kg})=\left(\left(\mathrm{BW}_{\mathrm{I}}+\mathrm{BW}_{\mathrm{F}}\right) /(1000 \times 2) ; B_{\mathrm{F}}, B_{\mathrm{I}}, B_{\mathrm{D}}\right.$, initial, final and dead biomasses $(\mathrm{g})$.

$N_{\text {Shrimp I }}$ and $N_{\text {ShrimpF }}$, initial and final $\mathrm{N}$ content of shrimp $(\mathrm{g} / 100 \mathrm{~g}$ fresh matter).

\section{Proximate analysis of diets and shrimp whole body}

At the beginning of the study, fifteen shrimp (12-h feed deprived) were selected for whole-body composition analyses. At the end of the trial, a pool of eight shrimp (12-h feed deprived) was analysed per treatment (two shrimp per tank). All samples were kept at $-20^{\circ} \mathrm{C}$ before analyses. Whole shrimp were ground and analysed for DM before being freeze dried. Gross energy content of feed samples was analysed using an adiabatic bomb calorimeter (IKA, Heitersheim, Germany). Feed samples as well as freeze-dried whole-body samples were analysed for DM $\left(105^{\circ} \mathrm{C}\right.$ for $\left.24 \mathrm{~h}\right)$, ash $\left(550^{\circ} \mathrm{C}\right.$ for $12 \mathrm{~h}$ ), lipid (Soxtherm, Gerhardt, Germany) and protein $(\mathrm{N} \times 6 \cdot 25$, Kjeldahl Nitrogen analyser 2000, Fison Instruments, Milan, Italy). Based on comparative carcass analyses, gain and retention values were computed. The AA composition of the diets was analysed (AgroBio Laboratory, Rennes, France) after hydrolysis $\left(6 \mathrm{M}-\mathrm{HCl}, 110^{\circ} \mathrm{C}, 23 \mathrm{~h}\right)$. After evaporation, samples were analysed in an automatic 
AA analyser (Biochrom-30, Biochrom Ltd, Cambridge, UK) using a sodium high resolution protein hydrolysate column (resin ultra pac 8). The AA were derivatised with ninhydrin and quantified at 570 and $440 \mathrm{~nm}$ for proline.

\section{Data analysis}

All data were analysed by a one-way ANOVA using dietary treatment as factor ( $n 11$ diets) or by a two-way ANOVA using the level of protein and of IAA (lysine or methionine) as independent factors ( $n 6$ diets), followed by the comparison of means using the Duncan's multiple range test in case of a significant effect $(P<0 \cdot 05)$. ANOVA was performed using STATISTICA 5.0 software (StatSoft, Inc., Tulsa, OK, USA).

Four regression models were used to estimate the maintenance ( $X$-value for zero gain) and growth requirements. The first models use a broken line (BLM) and a quadratic regression $^{(25)}$ :

$$
\text { BLM model: } Y=L+U(X-R) \quad \text { if } X>R,(X-R)=0 \text {. }
$$

Quadratic with one slope: $Y=L+U(X-R)(X-R)$

$$
\text { if } X>R,(X-R)=0
$$

where $Y$, dependent variable as $\mathrm{N}$ gain $(\mathrm{g} / \mathrm{kg} \mathrm{BW}$ per $\mathrm{d})$; $X$, independent variable as $\mathrm{N}$, lysine or methionine intake $(\mathrm{g} / \mathrm{kg} \mathrm{BW}$ per $\mathrm{d}) ; U$, slope of the first segment (nutrient utilisation efficiency); $R$, breakpoint $X$ value (maximal growth requirement value); $L$, plateau value.

Maintenance requirements $(Y=0)$ were calculated as: $X=(U R-L) / U$ with the BLM and as $X=R+\left(-(L / U)^{1 / 2}\right)$ with the quadratic model.

The third model used was the four parameters saturation nutrient kinetic model ${ }^{(26)}$ :

$$
Y=\frac{\left(\left(B \times K_{0.5^{n}}\right)+\left(R_{\max } \times X^{n}\right)\right)}{\left(K_{0.5}{ }^{n}+X^{n}\right)},
$$

where $Y$, dependent variable as $\mathrm{N}$ gain $(\mathrm{g} / \mathrm{kg} \mathrm{BW}$ per $\mathrm{d})$; $X$, independent variable as $\mathrm{N}$, lysine or methionine intake $(\mathrm{g} / \mathrm{kg} \mathrm{BW}$ per $\mathrm{d}) ; B$, intercept on $y$-axis for $X=0 ; K_{0.5}$, concentration for $1 / 2(R+B) ; R_{\max }$, maximum $Y$ response; $n$, apparent kinetic order.

Maintenance requirement $(Y=0)$ was calculated as: $X=\mathrm{K}_{0.5} \times\left(-B / R_{\max }\right)^{(1 / n)}$. Total requirement was estimated at $95 \%$ of the maximum gain $\left(R_{\max }\right)^{(27)}$ following the above equation. Therefore, requirement $(\mathrm{mg} / \mathrm{kg} \mathrm{BW}$ per d) was calculated as

$X=\left(\left(K_{0.5}^{n} \times\left(R_{\lim }-B\right)\right) /\left(R_{\max }-R_{\lim }\right)\right)^{(1 / n)} \quad$ with $R_{\lim }=R_{\max } \times 0.95$.

The fourth model was logistic model ${ }^{(28)}$ and described as

$$
Y=\frac{\left(R_{\max }+\left(\left(b \times(1+c)-R_{\max }\right) \times \mathrm{e}^{(-k X)}\right)\right)}{\left(1+\left(c \times \mathrm{e}^{(-k X)}\right)\right)},
$$

where $Y$, dependent variable as $\mathrm{N}$ gain $(\mathrm{g} / \mathrm{kg} \mathrm{BW}$ per $\mathrm{d}) ; X$, independent variable as $\mathrm{N}$, lysine or methionine intake $(\mathrm{g} / \mathrm{kg}$ BW per d); $b$, intercept on $y$-axis for $X=0 ; R_{\max }$, maximum $Y$ response; $c$, shaping parameter that locates the inflection point; $k$, scaling parameter.
Maintenance requirement $(Y=0)$ was calculated as $X=(-1 / k) \times \operatorname{Ln}\left(-R_{\max } /\left(b+b \times c-R_{\max }\right)\right)$.

Overall requirement $(\mathrm{g} / \mathrm{kg} \mathrm{BW}$ per d) estimated at $95 \%$ $R_{\max }{ }^{(29)}$ was calculated as

$X=\frac{\operatorname{Ln}\left(R_{\max }-R_{\max 0.95}\right)-\operatorname{Ln}\left(R_{\max 0.95} \times c-b-b \times c+R_{\max }\right)}{-k}$.

Marginal efficiency of nutrient utilisation was calculated as the first derivative $\mathrm{d} Y / \mathrm{d} X$, according to the following equation:

$\mathrm{d} Y / \mathrm{d} X=\frac{-k \times\left(b+b c-R_{\max }\right) \times \mathrm{e}^{(-k X)}+k \times c \times R_{\max } \times \mathrm{e}^{(-k X)}}{\left(1+c \times \mathrm{e}^{(-k X)}\right)^{2}}$.

Protein requirements were determined using data from NP, LP, MP and HP treatments. Lysine requirements were determined using data from treatments NP, LP, lysine-deficient LP, MP, lysine-deficient MP, HP and lysine-deficient HP (excluding the methionine-deficient diets), and methionine requirements were determined using those from treatments NP, LP, methionine-deficient LP, MP, methionine-deficient MP, HP and methionine-deficient HP (excluding the lysinedeficient diets). Four replicate tanks for each treatment $(n 4)$ were included in the analysis, except for HP ( $n$ 3) where one tank had to be excluded because of cannibalism. Graphical presentations and parameter estimates were made using GraphPad Prism 4.00 for Windows (GraphPad Software, San Diego, CA, USA).

\section{Results}

Table 4 shows the performances of the shrimp analysed by a one-way (effect treatment, $n$ 11) and two-way ANOVA (effect dietary protein and IAA level, $n 6$ diets). Results from the one-way ANOVA showed no significant effect of the dietary treatment on the survival of the shrimp (Table 4). FI (g/kg BW per d) in shrimp fed LP, MP and HP diets were higher than when fed NP diet or the practical diet (Table 4). The lowest final BW was found for shrimp fed the NP and LP diets $(2.3-3.6 \mathrm{~g})$, and the highest BW was found for those fed MP diets, the three HP diets and the practical diet (4.9-5.7 g), which were not significantly different. The deficient HP diets and the non-deficient MP diet led to similar growth rates, which were not different from growth rates obtained with the practical diet (Table 4). Among the experimental diets, LP and NP diets provided a significantly lower FE than MP or HP diets. The two-way ANOVA of the data in Table 4 showed a significant effect of the protein level on final $\mathrm{BW}$, specific growth rate and $\mathrm{FE}$ $(\mathrm{HP}=\mathrm{MP}>\mathrm{LP})$, but not on survival or FI. No significant effect of the IAA deficiency could be detected on any of the parameters (Table 4). Interestingly, for both IAA, the twoway ANOVA indicated a significant interaction between the levels of protein and IAA for growth performances (final BW and specific growth rate), which was more pronounced (lower $P$-value) for methionine than for lysine (Table 4). The interaction between the level of methionine and protein regarding growth, and also FE, can be explained by the fact that methionine deficiency reduced growth, and FE, at the MP level (methionine-deficient MP $v$. MP), but not at the higher or lower protein levels (Table 4). 
The analysis of whole-body composition of the shrimp (data not shown) revealed a low-lipid content $(0 \cdot 3-0.6 \mathrm{~g} / 100 \mathrm{~g}$ shrimp) and an ash content of 3.4-4.0 g/100 g shrimp, without visible effect of the dietary treatment. There was a positive linear relationship $\left(R^{2} 0.96\right)$ between the concentration of dietary and whole-body protein, which was $17 \cdot 4,19 \cdot 1,20 \cdot 2$ and $21.9 \mathrm{~g} / 100 \mathrm{~g}$ shrimp for NP, LP, MP and HP diets, respectively. As intended, $\mathrm{N}$ intakes (data not shown) differed largely between the dietary treatments, being significantly higher with HP diet $(5.7 \mathrm{~g} / \mathrm{kg} \mathrm{BW}$ per $\mathrm{d})$ than with MP or LP diets (3.6 and $1.5 \mathrm{~g} / \mathrm{kg} \mathrm{BW}$ per $\mathrm{d}$, respectively), and the lowest value being with the NP treatment $(0.4 \mathrm{~g} / \mathrm{kg} \mathrm{BW}$ per d). Daily $\mathrm{N}$ gain (per unit BW) was significantly affected by $\mathrm{N}$ intake: methionine-deficient HP-fed animals had the highest $N$ gain $(0.67 \mathrm{~g} / \mathrm{kg}$ BW per d), whereas NP-fed animals had a daily $\mathrm{N}$ loss of $0 \cdot 07 \mathrm{~g} / \mathrm{kg} \mathrm{BW}$ per d. Daily $\mathrm{N}$ gains of shrimp fed HP and MP diets were not significantly different from the $\mathrm{N}$ gain obtained with the commercial diet $(0.59-62 \mathrm{~g} / \mathrm{kg} \mathrm{BW}$ per d). Lysine or methionine deficiency did not affect the level of $\mathrm{N}$ intake or $\mathrm{N}$ gain $(P>0 \cdot 05)$. However, a significant interaction was found between dietary protein and methionine level on the daily $\mathrm{N}$ gain $(P=0.0026)$, related to the fact that the deficiency in methionine (Fig. 1(b)) affected $\mathrm{N}$ growth only at the MP level. Although the interaction between lysine and protein levels was not significant $(P=0 \cdot 055), \mathrm{N}$ gains presented in Fig. 1(a) show a similar tendency with the effect of a lysine deficiency being more pronounced at the medium than at lower or higher dietary protein levels.

\section{Protein and indispensable amino acid requirement estimates}

The four models used to estimate the requirements for $\mathrm{N}$, lysine and methionine all gave a satisfactory regression coefficient $\left(0.95<R^{2}<0.99\right.$; Table 5$)$. The four parameters saturation nutrient kinetic model gave the highest $\mathrm{N}$ requirement estimates and the BLM gave the lowest $\mathrm{N}$ requirement estimates (Tables 5 and 6). Based on the contrasting assumptions inherent to the model regarding nutrient utilisation efficiency (constant or diminishing returns) ${ }^{(28)}$, we decided to further comment the results obtained only with the BLM (Fig. 2) and the logistic (Fig. 3) model.

Nitrogen requirements for maintenance ( $\mathrm{N}$ equilibrium) and maximal $\mathrm{N}$ gain were estimated to be $0.6-0.7 \mathrm{~g} \mathrm{~N} / \mathrm{kg} \mathrm{BW}$ per $\mathrm{d}$ and $3 \cdot 1-3.8 \mathrm{~g} \mathrm{~N} / \mathrm{kg} \mathrm{BW}$ per $\mathrm{d}$, respectively, corresponding to CP levels of $4.1-4.5 \mathrm{~g}$ and $19.7-23.9 \mathrm{~g} / \mathrm{kg} \mathrm{BW}$ per $\mathrm{d}$ (Table 6, Figs. 2(a) and 3(a)). Regarding the requirements for lysine, using $\mathrm{N}$ gain as response, both models led to similar estimates, being $0 \cdot 18-0.20 \mathrm{~g} / \mathrm{kg} \mathrm{BW}$ per d for maintenance and $1.14-1.40 \mathrm{~g} / \mathrm{kg} \mathrm{BW}$ per d for maximal $\mathrm{N}$ gain (Table 6, Figs. 2(b) and 3(b)). Methionine requirement for maintenance or $\mathrm{N}$ balance was found to be $0 \cdot 10-0 \cdot 11 \mathrm{~g} / \mathrm{kg} \mathrm{BW}$ per $\mathrm{d}$, whereas that found for maximum $\mathrm{N}$ gain ranged from 0.56 to $0.70 \mathrm{~g} / \mathrm{kg} \mathrm{BW}$ per d (Table 6, Figs. 2(c) and 3(c)). Based on the above data, we could estimate the need as percentage of protein requirement, which was $5.8 \%$ for lysine $2.9 \%$ for methionine (Table 6). Maintenance requirements for protein represented $19-21 \%$ of the protein requirement for maximum

Table 4. Survival, feed intake, growth and nutrient utilisation in juvenile Penaeus monodon fed the semi-purified diets for 6 weeks (Mean values and standard deviations)

\begin{tabular}{|c|c|c|c|c|c|c|c|c|c|c|c|c|}
\hline \multirow[b]{2}{*}{ Dietary treatments } & \multicolumn{2}{|c|}{ Survival (\%) } & \multicolumn{2}{|c|}{ Final BW (g) } & \multicolumn{2}{|c|}{$\operatorname{SGR}(\% / d)$} & \multicolumn{2}{|c|}{$\mathrm{FI}(\mathrm{g} / \mathrm{kg} \mathrm{BW}$ per d) } & \multicolumn{2}{|c|}{ FE } & \multicolumn{2}{|c|}{$\begin{array}{c}\text { Nitrogen retention } \\
(\%)\end{array}$} \\
\hline & Mean* & $S D^{*}$ & Mean & SD & Mean & SD & Mean & SD & Mean & SD & Mean & SD \\
\hline NP & $80 \cdot 0$ & $14 \cdot 4$ & $2 \cdot 3^{\mathrm{e}}$ & 0.1 & $-0.01^{f}$ & 0.13 & $45 \cdot 3^{c}$ & $2 \cdot 6$ & $-0.001^{\mathrm{e}}$ & 0.031 & $-18 \cdot 7^{c}$ & $10 \cdot 7$ \\
\hline LP & $83 \cdot 3$ & 8.6 & $3 \cdot 2^{d}$ & 0.2 & $0.67^{e}$ & 0.19 & $64 \cdot 4^{a b}$ & $8 \cdot 3$ & $0.099^{d}$ & 0.014 & $13 \cdot 5^{b}$ & $2 \cdot 3$ \\
\hline LPM & $90 \cdot 0$ & $12 \cdot 8$ & $3 \cdot 6^{\mathrm{cd}}$ & 0.3 & $1.00^{d}$ & 0.27 & $71 \cdot 5^{\mathrm{ab}}$ & $5 \cdot 1$ & $0.134^{d}$ & 0.041 & $13 \cdot 1^{b}$ & $4 \cdot 1$ \\
\hline LPL & $90 \cdot 0$ & $15 \cdot 9$ & $3 \cdot 5^{d}$ & 0.3 & 0.90 de & 0.15 & $64 \cdot 8^{a b}$ & $6 \cdot 2$ & $0.134^{d}$ & 0.019 & $13 \cdot 7^{b}$ & $2 \cdot 0$ \\
\hline MP & $81 \cdot 7$ & $17 \cdot 5$ & $5 \cdot 2^{\mathrm{ab}}$ & 0.1 & $1 \cdot 82^{\mathrm{ab}}$ & 0.02 & $66 \cdot 5^{\mathrm{ab}}$ & $1 \cdot 8$ & $0.273^{b c}$ & 0.011 & $16 \cdot 2^{b}$ & 0.6 \\
\hline MPM & $78 \cdot 3$ & $18 \cdot 4$ & $4 \cdot 1^{c}$ & 0.2 & $1 \cdot 36^{\mathrm{C}}$ & 0.15 & $62 \cdot 5^{\mathrm{ab}}$ & $9 \cdot 0$ & $0 \cdot 219^{c}$ & 0.011 & $13 \cdot 9^{b}$ & $1 \cdot 1$ \\
\hline MPL & $78 \cdot 3$ & $10 \cdot 0$ & $4 \cdot 5^{\mathrm{bc}}$ & 0.3 & $1.58^{\mathrm{bc}}$ & 0.24 & $61 \cdot 4^{\mathrm{b}}$ & $7 \cdot 8$ & $0.255^{\mathrm{bc}}$ & 0.012 & $16 \cdot 8^{b}$ & 0.8 \\
\hline $\mathrm{HP}$ & $80 \cdot 0$ & $20 \cdot 0$ & $4 \cdot 9^{b}$ & 0.2 & $1.65^{b c}$ & 0.27 & $67 \cdot 1^{a b}$ & $1 \cdot 6$ & $0.235^{c}$ & 0.055 & $10 \cdot 9^{b}$ & $1 \cdot 3$ \\
\hline HPM & $80 \cdot 0$ & 14.4 & $5 \cdot 3^{a b}$ & 0.6 & $1.90^{\mathrm{ab}}$ & 0.30 & $66 \cdot 7^{\mathrm{ab}}$ & $4 \cdot 3$ & $0.270^{\mathrm{bc}}$ & 0.022 & $11 \cdot 5^{\mathrm{b}}$ & 0.8 \\
\hline $\mathrm{HPL}$ & $66 \cdot 7$ & 9.4 & $5 \cdot 7^{a}$ & 0.7 & $2.08^{a}$ & 0.22 & $73 \cdot 0^{a}$ & $10 \cdot 7$ & $0.290^{\mathrm{b}}$ & 0.062 & $10 \cdot 6^{b}$ & $2 \cdot 1$ \\
\hline Commercial & $86 \cdot 7$ & 6.7 & $5 \cdot 2^{a b}$ & 0.3 & $2 \cdot 01^{a}$ & 0.14 & $34.4^{d}$ & 1.5 & $0.529^{a}$ & 0.045 & $24 \cdot 7^{a}$ & $2 \cdot 3$ \\
\hline $\begin{array}{l}\text { Effect of diet (one-way } \\
\text { ANOVA) } \dagger\end{array}$ & 0.5944 & & $<0.0001$ & & $<0.0001$ & & $<0.0001$ & & $<0.0001$ & & $<0.0001$ & \\
\hline \multicolumn{13}{|c|}{ Effect of Lys and protein (two-way ANOVA) $\ddagger$} \\
\hline Protein & $0 \cdot 2103$ & & $<0.0001$ & & $<0.0001$ & & 0.2364 & & $<0.0001$ & & $<0.0001$ & \\
\hline Lys & 0.5739 & & 0.3753 & & 0.1115 & & 0.8903 & & 0.1137 & & 0.8580 & \\
\hline Protein $\times$ Lys & 0.4017 & & 0.0034 & & 0.0100 & & 0.3519 & & 0.1311 & & 0.9030 & \\
\hline \multicolumn{13}{|c|}{ Effect of Met and protein (two-way ANOVA) $\ddagger$} \\
\hline Protein & 0.6251 & & $<0.0001$ & & $<0.0001$ & & 0.5130 & & $<0.0001$ & & 0.0102 & \\
\hline Met & 0.8660 & & 0.5975 & & 0.7049 & & 0.7254 & & 0.6638 & & 0.4277 & \\
\hline Protein $\times$ Met & 0.8079 & & 0.0001 & & 0.0037 & & 0.1943 & & 0.0088 & & 0.4027 & \\
\hline
\end{tabular}

BW, body weight; SGR, specific growth rate; FE, feed efficiency; FI, feed intake; NP, non-protein; LP, low protein; LPM, methionine-deficient low-protein diet; LPL, lysine-deficient low-protein diet; MP, medium protein; MPM, methionine-deficient medium-protein diet; MPL, lysine-deficient medium-protein diet; HP, high protein; HPM, methionine-deficient high-protein diet; HPL, lysine-deficient high-protein diet.

${ }^{a-f}$ Mean values with different superscript letters were significantly different between groups $(P<0.05)$.

* $n 4$ per diet, except for HP and commercial diets for which $n 3$.

$\dagger P$ values given by the one-way ANOVA ( $n 11$ diets).

$\ddagger P$ values given by the two-way ANOVA ( $n 6$ diets per analysis). NP and commercial diets were excluded from the test, as well the Met-deficient diets from the ANOVA on the effect of Lys and the Lys-deficient diets from the ANOVA on the effect of Met. 

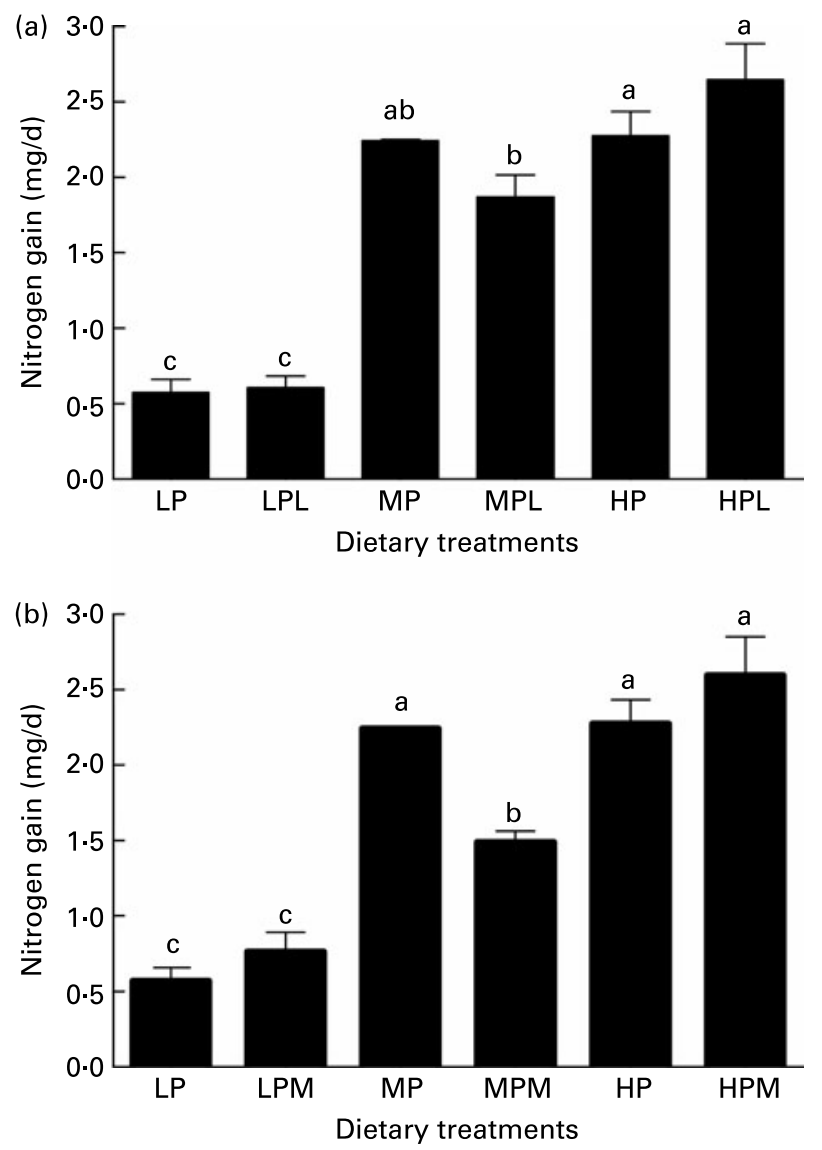

Fig. 1. Effect of dietary levels of protein and lysine (a) and protein and methionine (b) on daily individual nitrogen gain $(\mathrm{mg} / \mathrm{d})$ of juvenile Penaeus monodon fed the semi-purified diets for 6 weeks. LP, low protein; LPL, lysine-deficient LP; MP, medium protein; MPL, lysine-deficient MP; HP, high protein; HPL, lysine-deficient HP; LPM, methionine-deficient LP; MPM, methionine-deficient MP; HPM, methionine-deficient HP. Values are means (n 4 per treatment, except for HP where $n$ 3), with standard deviations represented by vertical bars. ${ }^{a, b, c}$ Mean values with unlike letters are significantly different $(P<0.05$; one-way ANOVA). $P$ values of the two-way ANOVA (protein $\times$ lysine) are as follows: protein, $P<0.0001$; lysine, $P=0.936$; protein $\times$ lysin, $P=0.055$. $P$ values of the two-way ANOVA (protein $\times$ methionine) are as follows: protein, $P<0.0001$; methionine, $P=0.503$; protein $\times$ methionine, $P=0.002$.

growth, whereas the maintenance/growth ratio was $14.5-$ $15.9 \%$ for lysine and between 16.4 and $17.4 \%$ for methionine (Table 6).

\section{Marginal efficiencies of nitrogen and indispensable amino acid utilisation}

The instantaneous marginal efficiency of $\mathrm{N}$ utilisation, calculated from the parameters obtained with the logistic model, showed a maximum efficiency of $38 \%$, occurring at an $\mathrm{N}$ intake level of $39 \%$ of that needed for maximum $\mathrm{N}$ gain (Fig. 3(a)). The BLM estimate of constant $\mathrm{N}$ utilisation efficiency between maintenance and maximal growth was $24 \%$ (Table 5). Lysine marginal efficiency, determined after plotting $\mathrm{N}$ gain against lysine intakes, peaked at 0.77 at a lysine intake level corresponding to $35.7 \%$ of the predicted requirement for maximum $\mathrm{N}$ gain (Fig. 3(b)). Methionine marginal efficiency reached a maximum of 1.62 corresponding to $37.1 \%$ of the requirement estimated for maximum $\mathrm{N}$ gain (Fig. 3(c)).

\section{Discussion}

The survival and whole-body mass increases of the shrimp fed the semi-purified MP and HP diets are comparable to those reported in other feeding trials with $P$. monodon of similar size ranges ${ }^{(30,31)}$. Only few studies with shrimp species applied a factorial approach to determine the part of $\mathrm{N}$ losses to be attributed to maintenance or to estimate $\mathrm{N}$ utilisation between maintenance and maximal growth response ${ }^{(5,12,13)}$. As for IAA requirements, there is, to our knowledge, no such data available for crustaceans. Some of the methodological dissimilarities between the present and latter studies with shrimp susceptible to affect requirement estimates $^{(32,33)}$ concern the feed supply, response criterion and mathematical model. In the present study, the different diets were fed on an ad libitum basis with careful monitoring of intakes instead of supplying a single diet at fixed ratios as in the study with $L$. vannamei ${ }^{(5)}$. In line with Teshima et al. ${ }^{(12,13)}$, protein accretion (daily $\mathrm{N}$ gain/unit $\mathrm{BW}$ ) was used as response rather than total weight ${ }^{(5)}$, considered less pertinent as response criterion than $\mathrm{N}$ accretion ${ }^{(28,34)}$. Regarding the model, we decided to focus on a linear (broken line) and non-linear (logistic) regression because of the contrasting assumptions regarding the marginal utilisation efficiency, the former assuming constant efficiency and the latter being recommended in vertebrates for the determination of diminishing returns when approaching maximal intake ${ }^{(35)}$.

\section{Protein requirements for maintenance and growth}

The maintenance requirement for protein, defined as the amount of protein ingested by the shrimp to maintain its $\mathrm{N}$ equilibrium ( $\mathrm{N}$ synthesis equals $\mathrm{N}$ breakdown), was estimated from both models at the $X$-intercept level. The protein requirements for maintenance for $P$. monodon estimated in the present study ( $2.4 \mathrm{~g}$ initial $\mathrm{BW})$ ranged between 4.1 and $4.5 \mathrm{~g} \mathrm{CP} / \mathrm{kg} \mathrm{BW}$ per $\mathrm{d}$, showing only minor variations according to the model used. These estimates are superior to data from juvenile $L$. vannamei $(1.8-3.8 \mathrm{~g} \mathrm{CP} / \mathrm{kg} \mathrm{BW}$ per d) using zero BW gain as a response parameter ${ }^{(5)}$. The low protein maintenance requirement of $0.2 \mathrm{~g} \mathrm{CP} / \mathrm{kg} \mathrm{BW}$ per $\mathrm{d}$ reported for $M$. rosenbergii (initial BW: $0 \cdot 15 \mathrm{~g})^{(13)}$ and of $1.1 \mathrm{~g} \mathrm{CP} / \mathrm{kg} \mathrm{BW}$ per $\mathrm{d}$ for $M$. japonicus (initial $\mathrm{BW}$ : $1.69 \mathrm{~g})^{(12)}$ reflects, in fact, the daily obligatory $\mathrm{N}$ losses at zero feed intake, which was assumed as reflecting maintenance requirements. If calculated in the same manner, daily $\mathrm{N}$ losses in the present study were $0.16 \mathrm{~g} / \mathrm{kg} \mathrm{BW}$ per $\mathrm{d}$, equivalent to $0.98 \mathrm{~g} \mathrm{CP} / \mathrm{kg} \mathrm{BW}$ per $\mathrm{d}$, a value close to that reported for $M$. japonicus ${ }^{(12)}$.

Protein requirement for maximum $\mathrm{N}$ gain in $P$. monodon juveniles ranged between 19.7 and $23.9 \mathrm{~g} \mathrm{CP} / \mathrm{kg} \mathrm{BW}$ per d, in line with the protein requirement for growth $(20.5-23.5 \mathrm{~g}$ $\mathrm{CP} / \mathrm{kg} \mathrm{BW}$ per d) reported for subadult L. vannamei ${ }^{(5)}$. The protein requirements of $7 \cdot 1 \mathrm{~g} \mathrm{CP} / \mathrm{kg} \mathrm{BW}$ per $\mathrm{d}$ found for $M$. rosenbergii ${ }^{(13)}$ and of $10 \mathrm{~g} \mathrm{CP} / \mathrm{kg} \mathrm{BW}$ per $\mathrm{d}$ for M. japonicus ${ }^{(12)}$ are lower than in the present study, possibly due to the relatively poor growth in their studies as compared 
to ours. It is also worth noting that in the present study growth of the shrimp fed the MP and HP semi-purified diets was similar to that obtained with a commercial practical diet.

The ratio between maintenance and growth requirement, which reflects the proportion of a nutrient used by an animal to maintain $\mathrm{N}$ balance as compared to that needed for maximal $\mathrm{N}$ gain, was about $20 \%$. This is much higher than the maintenance/growth ratio reported for $L$. vanname $i$ juveniles $(3.9-8.8 \%)$ and subadults $(6 \cdot 4-10 \cdot 2 \%)^{(5)}$, suggesting a relatively higher protein requirement for maintenance of $\mathrm{N}$ balance in juvenile $P$. monodon. However, the present maintenance/gain ratio is within the same range as found in juvenile teleost fish, i.e. $12.3 \%$ for Atlantic salmon (Salmo salar) fry ${ }^{(11)}, 15.1 \%$ in channel catfish (Ictalurus punctatus) fingerlings ${ }^{(9)}, 16.7 \%$ in juvenile Nile tilapia (Oreochromis niloticus) ${ }^{(36)}$ or $21 \%$ for juvenile two-banded seabream (Diplodus vulgaris) $^{(37)}$.

\section{Efficiency of protein utilisation for maximal nitrogen gain}

The study of marginal $\mathrm{N}$ utilisation efficiency, which reflects the efficiency of $\mathrm{N}$ utilisation between maintenance and maximum growth, depends on the biological assumption of constant efficiency or not, and thus the mathematical model. We found that marginal efficiency of $\mathrm{N}$ utilisation in $P$. monodon reached a maximum of 38 at $39 \%$ of the maximal growth requirement, after which $\mathrm{N}$ utilisation efficiency decreased to $5.6 \%$ at maximal $\mathrm{N}$ gain intake levels. Diminishing returns are important to consider from an economical perspective for choosing the requirement, with estimates for optimal utilisation efficiency occurring at lower $\mathrm{N}$ intakes than for optimal growth ${ }^{(35)}$. The average value of the marginal (instantaneous) efficiencies obtained with the logistic model was $24.9 \%$, which agrees well with the constant efficiency of $24 \%$ obtained with broken line model ( $U$ estimate). The comparison with other data from shrimp is difficult since no data on the regression coefficients were given (simple linear regression) ${ }^{(12,13)}$ or since weight gain rather than $\mathrm{N}$ gain $/ \mathrm{kg} \mathrm{BW}$ was used as response criterion without precision of efficiency values ${ }^{(5)}$. However, the present $\mathrm{N}$ utilisation efficiency $(24 \%)$ is inferior to values similarly obtained by broken line regression ${ }^{(33}$ )or simple linear regression $^{(10)}$ in other species, such as teleost fish showing $\mathrm{N}$ utilisation efficiencies as high as $37.9 \%$ for gilthead seabream (Sparus aurata) ${ }^{(10)}$ or $39.6 \%$ for European seabass (Dicentrarchus labrax) $^{(10)}$ and $34-44 \%$ for rainbow trout (Oncorhynchus mykiss) $^{(10,33)}$.

A more common parameter in nutritional studies on shrimp is total $\mathrm{N}$ retention, i.e. the ratio of total $\mathrm{N}$ gain to cumulated $\mathrm{N}$ intakes, without identification of the part of $\mathrm{N}$ losses due to maintenance. $\mathrm{N}$ retentions varied between 11 (HP diets) and $17 \%$ (lysine-deficient MP). Low $\mathrm{N}$ retentions, comprised

Table 5. Parameters estimated by fitting the four regression models through the experimental data using nitrogen gain ( $\mathrm{g} / \mathrm{kg}$ body weight (BW) per d) as the response parameter and the different intake levels of nitrogen, lysine or methionine ( $\mathrm{g} / \mathrm{kg}$ BW per $\mathrm{d})$ as input parameter in Penaeus monodon

(Mean values with their standard errors)

\begin{tabular}{|c|c|c|c|c|c|c|c|}
\hline \multirow[b]{3}{*}{ Models } & \multirow[b]{3}{*}{ Parameter estimates } & \multicolumn{6}{|c|}{ Estimated requirement } \\
\hline & & \multicolumn{2}{|c|}{ Nitrogen } & \multicolumn{2}{|c|}{ Lys } & \multicolumn{2}{|c|}{ Met } \\
\hline & & Mean & SE & Mean & SE & Mean & SE \\
\hline \multirow[t]{6}{*}{ BLM } & $L$ & 0.60 & 0.02 & 0.62 & 0.01 & 0.63 & 0.02 \\
\hline & $U$ & 0.24 & 0.03 & 0.65 & 0.04 & 1.35 & $0 \cdot 10$ \\
\hline & $R$ & $3 \cdot 14$ & 0.25 & $1 \cdot 14$ & 0.05 & 0.56 & 0.03 \\
\hline & df & 12 & & 24 & & 24 & \\
\hline & $R^{2}$ & 0.98 & & 0.96 & & 0.95 & \\
\hline & $S_{y, x}$ & 0.04 & & 0.05 & & 0.06 & \\
\hline \multirow[t]{6}{*}{ Quad-1 } & $L$ & 0.64 & 0.02 & 0.63 & 0.02 & 0.66 & 0.03 \\
\hline & $U$ & -0.03 & 0.00 & -0.26 & 0.04 & -1.02 & $0 \cdot 17$ \\
\hline & $R$ & 5.03 & 0.39 & $1 \cdot 75$ & 0.14 & 0.90 & 0.07 \\
\hline & df & 12 & & 24 & & 24 & \\
\hline & $R^{2}$ & 0.98 & & 0.96 & & 0.95 & \\
\hline & $S_{y, x}$ & 0.04 & & 0.06 & & 0.06 & \\
\hline \multirow[t]{7}{*}{ SK-4 } & $B$ & -0.07 & 0.02 & -0.06 & 0.03 & -0.07 & 0.03 \\
\hline & $K_{0.5}$ & $1 \cdot 74$ & 0.12 & 0.62 & 0.05 & 0.31 & 0.02 \\
\hline & $n$ & $3 \cdot 11$ & 0.75 & 2.48 & 0.50 & 2.90 & 0.59 \\
\hline & $R_{\max }$ & 0.65 & 0.04 & 0.68 & 0.04 & 0.68 & 0.04 \\
\hline & df & 11 & & 23 & & 23 & \\
\hline & $R^{2}$ & 0.99 & & 0.95 & & 0.96 & \\
\hline & $S_{y, x}$ & 0.04 & & 0.06 & & 0.06 & \\
\hline \multirow[t]{7}{*}{ Logistic } & $R_{\max }$ & 0.63 & 0.03 & 0.64 & 0.02 & 0.65 & 0.03 \\
\hline & $b$ & -0.12 & 0.03 & -0.09 & 0.04 & -0.10 & 0.04 \\
\hline & $c$ & $8 \cdot 61$ & 7.57 & $6 \cdot 85$ & 4.92 & 7.65 & $5 \cdot 71$ \\
\hline & $k$ & 1.41 & 0.42 & 3.69 & 0.87 & $7 \cdot 57$ & 1.89 \\
\hline & df & 11 & & 23 & & 23 & \\
\hline & $R^{2}$ & 0.99 & & 0.96 & & 0.96 & \\
\hline & $S_{y, x}$ & 0.04 & & 0.06 & & 0.06 & \\
\hline
\end{tabular}

BLM, broken line model; Quad-1, quadratic model with one slope; SK-4, four parameters saturation kinetic model; df, degrees of freedom. 
Table 6. Estimated requirements for nitrogen equilibrium (maintenance, $M$ ) and maximal nitrogen gain (nitrogen growth, G) for nitrogen, protein lysine and methionine using the four regression models for juvenile Penaeus monodon

\begin{tabular}{lrrrr}
\hline Requirement estimates & BLM & Quad-1 & SK-4 & Logistic \\
\hline Nitrogen (g/kg BW per d) & & & & \\
M & 0.65 & 0.63 & 0.86 & 0.73 \\
G & 3.15 & 5.03 & 4.65 & 3.82 \\
Protein (g/kg BW per d) & & & & \\
M & 4.06 & 3.94 & 5.36 & 4.53 \\
G & 19.66 & 31.46 & 29.05 & 23.89 \\
M/G (\%) & 20.64 & 12.52 & 18.47 & 18.98 \\
Lys (g/kg BW per d) & & & & \\
M & 0.18 & 0.18 & 0.24 & 0.20 \\
G & 1.14 & 1.75 & 2.11 & 1.40 \\
M/G (\%) & 15.92 & 10.34 & 11.33 & 14.46 \\
Met (g/kg BW per d) & & & & \\
M & 0.10 & 0.10 & 0.14 & 0.11 \\
G & 0.56 & 0.90 & 0.90 & 0.70 \\
M/G (\%) & 17.45 & 10.80 & 16.00 & 16.39 \\
Lys:Met ratio & 1.86 & 1.86 & 1.66 & 1.77 \\
M & 2.04 & 1.94 & 2.35 & 2.01 \\
G & & & & \\
Lys (\% CP) $\dagger$ & 4.49 & 4.60 & 4.45 & 4.46 \\
M & 5.82 & 5.56 & 7.25 & 5.85 \\
G & & & & \\
Met (\% CP) $\dagger$ & 2.41 & 2.47 & 2.67 & 2.51 \\
M & 2.86 & 2.86 & 3.09 & 2.91 \\
G & & & \\
\hline
\end{tabular}

BLM, broken line model; Quad-1, quadratic model with one slope; SK-4, four parameters saturation kinetic model; BW, body weight.

* Nitrogen requirement $\times 6.25$.

†Calculated ratio $=100 \times($ stimated indispensable amino acid requirement/ estimated protein requirement)

between 10 and $15 \%$ of $\mathrm{N}$ intakes, were also reported for adult Litopenaeus stylirostris under laboratory conditions ${ }^{(38)}$. The $\mathrm{N}$ retention obtained with the commercial treatment $(24.7 \%)$ agrees with $\mathrm{N}$ retentions in intensive shrimp farms in which approximately $20 \%$ of total dietary $\mathrm{N}$ input was recovered in the harvested $P$. monodon ${ }^{(39,40)}$. Higher $\mathrm{N}$ retentions of up to $31 \%$ for P. monodon ${ }^{(41)}$ or up to $46 \%$ of $\mathrm{N}$ input for post-larval L. vannamei ${ }^{(42)}$ have been attributed to the natural productivity (development of bacteria and phytoplankton populations) taking place in a static system (without water renewal), which constitutes a source of $\mathrm{N}$ intake and, hence, might overestimate $\mathrm{N}$ retention. In the present study, the water renewal ( $>40 \%$ of each tank/d) is believed to have maintained the recycling of $\mathrm{N}$ wastes through natural productivity close to zero. Although special care was taken for monitoring intakes, efficiencies of $\mathrm{N}$ utilisation with the experimental diets might be slightly underestimated due to some unseen feed losses or to leaching related to the slow feeding behaviour of the shrimp, as underlined before by others ${ }^{(12)}$. Also the loss of exuvia during the growth of the animal, not taken into consideration in the present work, accounts for a part of $\mathrm{N}$ losses, which leads to underestimation of actual $\mathrm{N}$ retentions.

\section{Lysine and methionine requirements for nitrogen maintenance and maximal nitrogen gain}

Data obtained here on lysine and methionine requirements for maintenance are the first ever estimates of IAA requirements for $\mathrm{N}$ balance in crustacean shrimp. The proportion of ingested $\mathrm{AA}$ spent to cover the $\mathrm{N}$ maintenance requirement as compared to the requirement for maximal $\mathrm{N}$ gain was $14.5-15.9 \%$ for lysine and $16.4-17.4 \%$ for methionine. The similarity in maintenance contributions to total requirement for both IAA differs from the lower maintenance contribution for lysine than methionine reported in rainbow trout $(4 \%$ for lysine v. $10 \%$ for methionine $)^{(34)}$ or in growing pigs $(6 \%$ for lysine $v .12 \%$ for sulphur AA) ${ }^{(43)}$. In this respect, it would be of interest to evaluate the contributions at zero AA gain, given the possible underestimation of requirement based on $\mathrm{N}$ gain, related to shifts in the mobilisation of the type of body protein at intake levels near maintenance ${ }^{(35,44)}$.

Expressing the current lysine and methionine requirements for maximal $\mathrm{N}$ gain $(1.1-1.4$ and $0.6-0.7 \mathrm{~g} / \mathrm{kg} \mathrm{BW}$ per $\mathrm{d}$, respectively) as a proportion of protein requirement enables comparisons with the two other studies available in literature on lysine and methionine requirements for growth of the same species. Expressed this way, the lysine and methionine requirements for maximal $\mathrm{N}$ gain $(5.8$ and $2.9 \%$ of the protein requirement) are very close to the lysine requirement of $5.2 \%$ and the methionine requirement of $2.4 \%$ reported for postlarval P. monodon (approximately $20 \mathrm{mg}$ initial BW) using the dose-response technique ${ }^{(14,17)}$. The above requirements, however, exceed those found for L. vannamei, being 4.5$5.2 \%$ for lysine ${ }^{(45)}$ and only $1.26 \%$ for methionine ${ }^{(46)}$. Expressing maintenance requirements the same way $(\mathrm{g} / 16 \mathrm{~g} \mathrm{~N})$, the proportion of protein requirement for maintenance covered by both IAA was only slightly less than that seen for maximal growth, being $4.5 \%$ for lysine (using both models) and $2.4-$ $2.5 \%$ for methionine. Lower contribution of IAA to maintenance than to growth $(\mathrm{g} / 16 \mathrm{~g} \mathrm{~N})^{(8,10,26,47)}$ can be partly explained by the sparing of IAA due to the preferential oxidation of dispensable $\mathrm{AA}$ at $\mathrm{N}$ equilibrium, as suggested very early in the rats displaying lower requirements for IAA than for dispensable
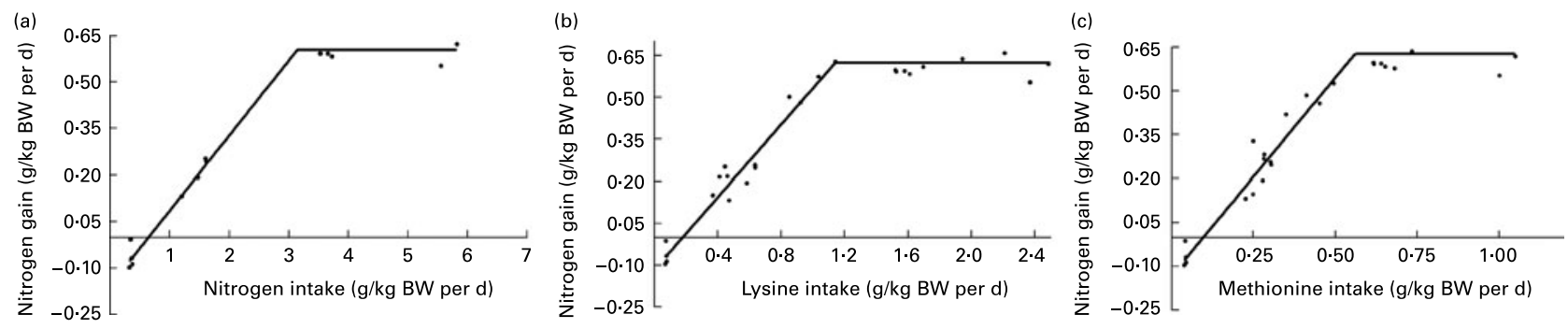

Fig. 2. Linear broken line regressions (broken line model) of nitrogen gain $v$. nitrogen intake (a), lysine intake (b) and methionine intake (c) in juvenile Penaeus monodon. The parameters of the regression equations and the requirement estimates are summarised in Tables 5 and 6 . BW, body weight. 
(a)

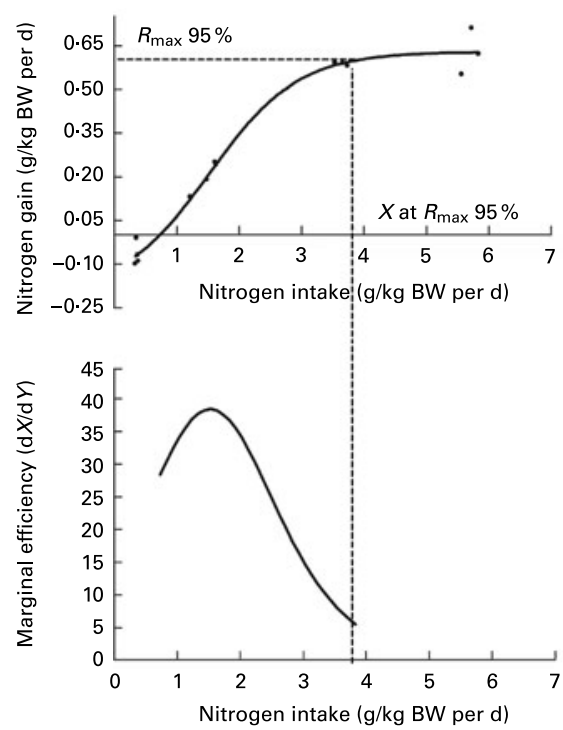

(b)

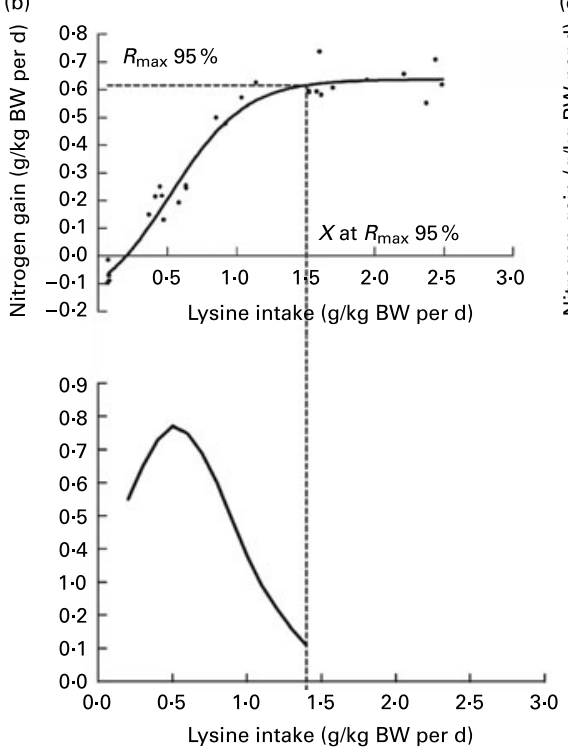

(c)

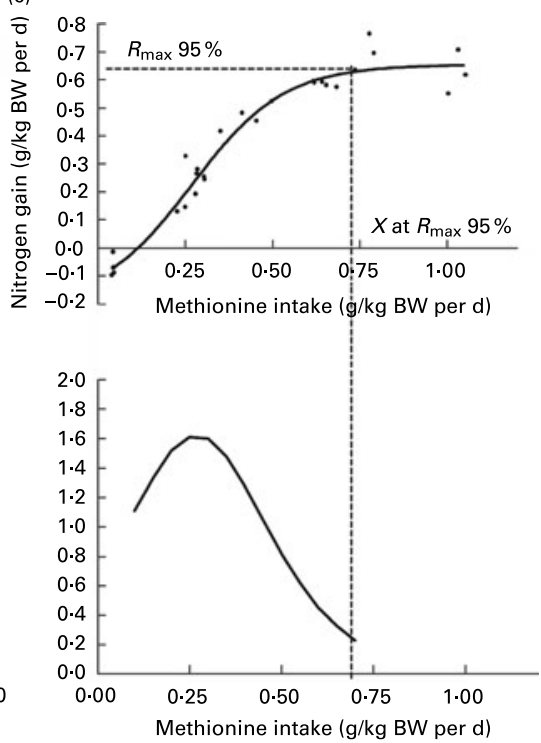

Fig. 3. Non-linear regressions obtained with the logistic model of nitrogen gain $v$. nitrogen intake (a), lysine intake (b) and methionine intake (c) and their respective marginal efficiencies in juvenile Penaeus monodon. The six indispensable amino acid-deficient diets were excluded from the model (a). The three methionineand lysine-deficient diets were excluded from the models (b) and (c), respectively. The parameters of the regression equations and the requirement estimates are summarised in Tables 5 and 6. Marginal instantaneous utilisation efficiency is defined as the incremental response in nitrogen gain per incremental unit of nitrogen intake (a), lysine intake (b) and methionine intake (c).

AA near maintenance ${ }^{(48)}$ and in chickens for which dispensable AA were suggested to maintain and replete protein reserves ${ }^{(49)}$. In salmon fry, dispensable AA enabled a reduction in $\mathrm{N}$ losses, suggesting their implications in protein metabolism under maintenance conditions ${ }^{(50)}$.

The ideal protein concept has been applied in IAA requirement studies for both terrestrial and aquatic species ${ }^{(51-54)}$, including crustaceans ${ }^{(14,15)}$. In the present study, the AA profile of the balanced diets (LP, MP and HP) was based on a range of published AA profiles of $P$. monodon whole body. The created deficiency in lysine was probably not sufficient to impact growth performances of the shrimps, although a tendency for lower $\mathrm{N}$ gain was observed at the MP level. In contrast, methionine deficiency affected significantly $\mathrm{N}$ gains, however, only at the MP level, but not with the LP or HP diets. This interaction between methionine and dietary protein indicates that requirements for IAA, when expressed as $\% \mathrm{CP}$, should be evaluated together with requirements for protein, as in the present and some other mentioned studies ${ }^{(7,10,33,55)}$.

Interestingly, growth of the shrimp was not depressed by supplying excess $\mathrm{N}$. Moreover, at intake levels exceeding $\mathrm{N}$ requirements, imbalances in the dietary IAA profile did not negatively affect FI or growth, as shown by the similarity in performances between shrimp fed the methionine-deficient HP or the balanced HP diet. This observation hence suggests that the ideal protein concept of 'a perfect and constant ratio among individual IAA and dietary $\mathrm{N}^{\prime(53)}$ should be applied only up to the $\mathrm{N}$ intake level providing maximal $\mathrm{N}$ gain, in line with broiler studies showing that lysine requirements are to be expressed as \% CP at intake levels below but not above protein requirement ${ }^{(56)}$. Also in kittens, increasing dietary CP while keeping methionine levels (\% diet) constant did not reduce growth or feed intake ${ }^{(57)}$, in contrast to earlier findings, referred to as AA imbalances, in rat and other animals ${ }^{(58)}$. These aspects are important to consider when poor-quality proteins are included at higher than normal levels to provide a minimal level of IAA in the diet.

\section{Efficiency of lysine and methionine utilisation for nitrogen gain}

For vertebrates, a large debate continues to exist as to whether marginal IAA utilisation for growth ( $\mathrm{N}$ or AA gain) is constant $^{(4,11,21,43,44,59-62)}$ or $\operatorname{not}^{(27,28,33-35,63,64)}$. Because of this uncertainty and the fact that there is currently no such information for crustaceans, we compared efficiency values for both IAA obtained with the broken line and logistic regression, which fitted the data equally well $\left(R^{2}>0.95\right)$. Based on the logistic model, the instantaneous efficiency ( $\mathrm{N}$ gain/g AA intake) reached a maximum of 0.77 for lysine and of 1.62 for methionine, whereas diminishing returns in $\mathrm{N}$ gain began, respectively, at an intake level of 37.1 and $35.7 \%$ of that required for maximal $\mathrm{N}$ gain. This observation is consistent with data from growing rats in which diminishing return responses in $\mathrm{N}$ gain started for each of the ten IAA at less than $40 \%$ of maximum gain ${ }^{(28)}$. In the same line, highest efficiencies were observed in rats fed diets providing 30-60\% of the requirement of the limiting IAA ${ }^{(62)}$. Assuming a linear relationship between $\mathrm{AA}$ intake and $\mathrm{N}$ gain and thus a constant efficiency value, the marginal efficiency ( $\mathrm{N}$ gain/g AA intake) of AA utilisation in the present study was 0.65 for lysine and 1.35 for methionine ( $U$ slopes BLM). The latter value agrees well with the efficiency of lysine utilisation for protein gain generally accepted in pigs $(0.55-0.65)^{(43)}$. Regarding the efficiency of methionine utilisation, studies in terrestrial animals suggest that the growth response to changes in methionine intake depends on the presence of other dietary substrates (cystine, choline and betaine), which may spare the use of dietary methionine for metabolic processes (such as transmethylation to $S$-adenosylmethionine 
and transulphuration to cystine) other than for lean body growth $^{(65)}$. In this respect, in the presence of excess cystine, methionine retention in growing pigs was found to be a linear function of methionine intake (ranging from 45 to $90 \%$ of the requirement) ${ }^{(47)}$. When both cystine and methionine are limiting, e.g. as in the present study by keeping cystine/methionine $(0 \cdot 3 / 1)$ ratios constant, the increased demand for non-protein synthesis may result in decreased methionine utilisation ${ }^{(65)}$. For $P$. monodon or other shrimp species, the relative contribution of cystine to the total sulphur AA requirement and the effect of cystine on methionine utilisation still remain to be elucidated.

\section{Acknowledgements}

The authors acknowledge the team of the Aqualma facility, with a special thanks to Christian Ramamonjisoa, Abel Randrianandrazana and Andry Rakotojaona for their technical assistance. From the Institut National de la Recherche Agronomique team, special thanks are due to Christiane Vachot, Fred Terrier and Peyo Aguirre for their help during diet manufacturing and to Marie Jo Borthaire for assistance with the laboratory analyses. P.-P. B. and V. R. contributed to the organisation of the experiments in Madagascar. S. J. K. and I. G. designed the study. L. R. did the data analysis. L. R., S. J. K. and I. G. contributed to the drafting of the paper. There are no contractual agreements for the presented data, which might cause conflicts of interest. The authors acknowledge UNIMA and institutional funds from Institut National de la Recherche Agronomique for funding the present study and Association Nationale de la Recherche Technique (France) for the scholarship to L. R. (CIFRE PhD Research Grant).

\section{References}

1. Food and Agricultural Organisation (FAO) (2007) FAO Fisheries Department, Fishery Information, Data and Statistics Unit. FISHSTAT Plus; Universal software for statistical time series, version 2.3 .

2. Shiau SY \& Chou BS (1991) Effects of dietary protein and energy on growth performance of tiger shrimp Penaeus monodon reared in seawater. Nippon Suisan Gakkaishi 57, 2271-2276.

3. Shiau SY (1998) Nutrient requirements of penaeid shrimp. Aquaculture 164, 77-93.

4. Rollin X, Mambrini M, Abboudi T, et al. (2003) The optimum dietary indispensable amino acid pattern for growing Atlantic salmon (Salmo salar L.) fry. Br J Nutr 90, 865-876.

5. Kureshy N \& Davis DA (2002) Protein requirement for maintenance and maximum weight gain for the Pacific white shrimp, Litopenaeus vannamei. Aquaculture 204, 125-143.

6. Venero JA, Davis DA \& Rouse DB (2007) Variable feed allowance with constant protein input for the pacific white shrimp Litopenaeus vannamei reared under semi-intensive conditions in tanks and ponds. Aquaculture 269, 490-503.

7. Wang TC \& Fuller MF (1989) The optimum dietary amino acid pattern for growing pigs. 1. Experiments by amino acid deletion. Br J Nutr 62, 77-89.

8. Fuller MF, McWilliam R, Wang TC, et al. (1989) The optimum dietary amino acid pattern for growing pigs. 2. Requirements for maintenance and for tissue protein accretion. Br J Nutr 62, $255-267$
9. Gatlin DM III, Poe WE \& Wilson RP (1986) Protein and energy requirement of fingerling channel catfish for maintenance and maximum growth. J Nutr 116, 2121-2131.

10. Fournier V, Gouillou-Coustans MF, Métailler R, et al. (2002) Protein and arginine requirements for maintenance and nitrogen gain in four teleosts. Br J Nutr 87, 459-469.

11. Abboudi T, Mambrini M, Ooghe W, et al. (2006) Protein and lysine requirements for maintenance and for tissue accretion in Atlantic salmon (Salmo salar) fry. Aquaculture 261, 369-383.

12. Teshima S, Koshio S, Ishikawa M, et al. (2001) Protein requirement of the prawn Marsupenaeus japonicus estimated by a factorial method. Hydrobiologia 449, 293-300.

13. Teshima S, Koshio S \& Ishikawa M (2006) Protein requirement of the freshwater prawn Macrobrachium rosenbergii evaluated by the factorial method. J World Aquacult Soc 37, 145-153.

14. Millamena OM, Bautista-Teruel MN, Reyes OS, et al. (1998) Requirements of juvenile marine shrimp, Penaeus monodon (Fabricius) for lysine and arginine. Aquaculture 164, 95-104.

15. Alam MS, Teshima S, Yaniharto D, et al. (2002) Dietary amino acid profiles and growth performance in juvenile kuruma prawn Marsupenaeus japonicus. Comp Biochem Physiol B 133, 289-297.

16. Gatlin DM III, Barrows FT, Brown P, et al. (2007) Expanding the utilization of sustainable plant products in aquafeeds: a review. Aquacult Res 38, 551-579.

17. Millamena OM, Bautista-Teruel MN \& Kanazawa A (1996) Methionine requirement of juvenile tiger shrimp Penaeus monodon Fabricius. Aquaculture 143, 403-410.

18. Gous RM (2007) Predicting nutrient responses in poultry: future challenges. Animal 1, 57-65.

19. Gous RM \& Morris TR (1985) Evaluation of a diet dilution technique for measuring the response of broiler chickens to increasing concentrations of lysine. Br Poult Sci 26, 147-161.

20. Abboudi T, Ooghe W, Larondelle Y, et al. (2007) Determination of the threonine requirement for maintenance in Atlantic salmon (Salmo salar L.) fry with the diet dilution procedure. Aquacult Nutr 13, 281-290.

21. Heger J, Phung TV, Krizova L, et al. (2003) Efficiency of amino acid utilisation in the growing pig at suboptimal levels of intake: branched-chain amino acids, histidine and phenylalanine + tyrosine. J Anim Physiol Anim Nutr 87, 52-65.

22. Morris TR, Gous RM \& Fisher C (1999) An analysis of the hypothesis that amino acid requirements for chicks should be stated as a proportion of dietary protein. World's Poult Sci J $\mathbf{5 5}, 7-22$.

23. Sterling KG, Pesti GM \& Bakalli RI (2003) Performance of broiler chicks fed various levels of dietary lysine and crude protein. Poult Sci 82, 1939-1947.

24. Mambrini M \& Kaushik SJ (1995) Effect of temperature on sulfur amino acid requirements for maintenance and growth of juvenile rainbow trout. In Protein Metabolism and Nutrition, pp. 117-122 [AF Nunes, AV Portugal, JP Costa and JR Ribeiro, editors]. Santarém: INIA.

25. Robbins KR, Saxton AM \& Southern LL (2006) Estimation of nutrient requirements using BLM regression analysis. J Anim Sci 84, 155-165.

26. Mercer LP (1982) The quantitative nutrient-response relationship. J Nutr 112, 560-566.

27. Rodehutscord M, Jacobs S, Pack M, et al. (1995) Response of rainbow trout (Oncorhynchus mykiss) growing from 50 to $150 \mathrm{~g}$ to supplements of DL-methionine in a semipurified diet containing low or high levels of cystine. J Nutr 125, 964-969.

28. Gahl MJ, Finke MD, Crenshaw TD, et al. (1991) Use of a fourparameter logistic equation to evaluate the response of growing rats to ten levels of each indispensable amino acid. J Nutr 121, $1720-1729$. 
29. Finke MD, DeFoliart G \& Benevenga NJ (1989) Use of a four parameter logistic model to evaluate the quality of the protein from three insect species when fed to rats. $J$ Nutr 119, $864-871$

30. Glencross BD, Smith DM, Tonks ML, et al. (1999) A reference diet for nutritional studies of the giant tiger prawn Penaeus monodon. Aquacult Nutr 5, 33-39.

31. Glencross BD \& Smith DM (1999) The dietary linoleic and linolenic fatty acids requirements of the prawn Penaeus monodon. Aquacult Nutr 5, 53-63.

32. Fuller MF \& Garthwaite P (1993) The form of response of body protein accretion to dietary amino acid supply. J Nutr 123, 957-963.

33. Bodin N, Govaerts B, Abboudi T, et al. (2009) Protein level affects the relative lysine requirement of growing rainbow trout (Oncorhynchus mykiss) fry. Br J Nutr 102, 37-53.

34. Rodehutscord M, Becker A, Pack M, et al. (1997) Response of rainbow trout (Oncorhynchus mykiss) to supplements of individual indispensable amino acids in a semipurified diet, including an estimate of the maintenance requirement for indispensable amino acids. $J$ Nutr 126, 1166-1175.

35. Gahl MJ, Crenshaw TD \& Benevenga NJ (1994) Diminishing returns in weight, nitrogen, and lysine gain of pigs fed six levels of lysine from three supplemental sources. J Anim Sci 72, 3177-3187.

36. Kaushik SJ, Doudet T, Médale F, et al. (1995) Protein and energy needs for maintenance and growth of Nile tilapia (Oreochromis niloticus). J Appl Ichtyol 11, 290-296.

37. Ozorio ROA, Valente LMP, Correia S, et al. (2009) Protein requirement for maintenance and maximum growth of twobanded seabream (Diplodus vulgaris) juveniles. Aquacult Nutr 15, 85-93.

38. Gauquelin F, Cuzon G, Gaxiola G, et al. (2007) Effect of dietary protein level on growth and energy utilisation by Litopenaeus stylirostris under laboratory conditions. Aquaculture 271, 439-448.

39. Briggs MRP \& Funge-Smith SJ (1994) A nutrient budget of some intensive marine shrimp ponds in Thailand. Aquacult Fish Manage 25, 789-811.

40. Jackson C, Preston N, Thompson P, et al. (2003) Nitrogen budget and effluent nitrogen components at an intensive shrimp farm. Aquaculture 218, 397-411.

41. Thakur DP \& Lin CK (2003) Water quality and nutrient budget in closed shrimp (Penaeus monodon) culture systems. Aquacult Eng 27, 159-176.

42. Perez-Velazquez M, Gonzalez-Felix MI, Gomez-Jimenez S, et al. (2008) Nitrogen budget for a low salinity. Zero water exchange culture system: II. Evaluation of isonitrogenous feeding of various dietary protein levels to Litopenaeus vannamei (Boone). Aquacult Res 39, 995-1004.

43. Heger J, Van Phung T \& Krizova L (2002) Efficiency of amino acid utilisation in the growing pig at suboptimal levels of intake: lysine, threonine, sulphur amino acids and tryptophan. J Anim Physiol Anim Nutr 86, 153-165.

44. Edwards HM, Fernandez SR \& Baker DH (1999) Maintenance lysine requirement and efficiency of using lysine for accretion of whole-body lysine and protein in young chick. Poult Sci 78, $1412-1417$.

45. Fox JM, Lawrence AL \& Li-Chan E (1995) Dietary requirement for lysine by juvenile Penaeus vannamei using intact and free amino acid sources. Aquaculture 131, 279-290.

46. Fox JM, Davis DA, Wilson M, et al. (2006) Current status of amino acid requirement research with marine penaeid shrimp. In Avances en Nutricion Acuicola, VIII Symposium Internacional de Nutricion Acuicola (Advances in aquaculture nutrition, VIII International Symposium on Aquaculture Nutrition), pp. 29-54 [LEC Suarez, DR Marie, MT Salazar, MGN Lopez, DAV
Cavazos, ACP Cruz and AG Ortega, editors]. Nuevo Leon: Universidad Autonoma de Nuevo Leon, ISBN 970-694-333-5.

47. Chung TK \& Baker DH (1992) Efficiency of dietary methionine utilisation by young pigs. J Nutr 122, 1862-1869.

48. Dreyer JJ (1976) Biological assessment of protein quality. Optimal indispensable:non-indispensable amino acid ratios for maintenance of certain states of nitrogen balance in young rats. S Afr Med J 50, 1521-1528.

49. Shapiro R \& Fisher H (1962) Protein reserves: relationship of dietary indispensable and non-indispensable amino acids to formation and maintenance in the fowl. J Nutr 76, 106-112.

50. Abboudi T, Mambrini M, Larondelle Y, et al. (2009) The effect of dispensable amino acids on nitrogen and amino acid losses in Atlantic salmon (Salmo salar L.) fry fed a protein-free diet. Aquaculture 289, 327-333.

51. Mambrini M \& Kaushik SJ (1995) Indispensable amino acid requirements of fish: correspondance between quantitative data and amino acid profiles of tissue proteins. J Appl Ichtyol 11, 240-247.

52. Kaushik SJ (1998) Whole body amino acid composition of European seabass (Dicentrarchus labrax), gilthead seabream (Sparus aurata) and turbot (Psetta maxima) with an estimation of their IAA requirement profiles. Aquat Liv Resour 11, 355-358.

53. Boisen S, Hvelplund T \& Weisbjerg MR (2000) Ideal amino acid profiles as a basis for feed protein evaluation. Livestock Prod Sci 64, 239-251.

54. Furuya WM, Pezzato LE, Barros MM, et al. (2004) Use of ideal protein concept for precision formulation of amino acid levels in fish-meal-free diets for juvenile Nile tilapia (Oreochromis niloticus L.). Aquacult Res 35, 1110-1116.

55. Nang TTT, Parkouda C, de Saeger S, et al. (2009) Protein level does not affect lysine utilisation efficiency at marginal lysine intake in growing rainbow trout (Oncorhynchus mykiss) fry. Aquaculture 288, 312-320.

56. Urdaneta-Rincon M, de Lange K, Pena-Ortega L, et al. (2005) Lysine requirements of young broiler chickens are affected by level of dietary crude protein. Can J Anim Sci 85, 195-204.

57. Strieker MJ, Morris JG, Kass PH \& Rogers QR (2007) Increasing the dietary crude protein does not increase the methionine requirement in kittens. J Anim Physiol Anim Nutr 91, 465-474.

58. Harper AE, Benevenga NJ \& Wohlhueter RM (1970) Effects of ingestion of disproportionate amounts of amino acids. Physiol Rev 50, 428-557.

59. Hauler RC, Carter CG \& Edwards SJ (2007) Feeding regime does not influence lysine utilisation by Atlantic salmon, Salmo salar L. parr. Aquaculture 273, 545-555.

60. Rollin X, Wauters JB, Bodin N, et al. (2006) Maintenance threonine requirement and efficiency of its use for accretion of whole-body threonine and protein in Atlantic salmon (Salmo salar L.) fry. Br J Nutr 95, 234-245.

61. Edwards HM \& Baker DH (1999) Maintenance sulphur amino acid requirements of young chicks and efficiency of their use for accretion of whole-body sulphur amino acids and protein. Poult Sci 78, 1418-1423.

62. Heger J \& Frydrych Z (1985) Efficiency of utilisation of indispensable amino acids in growing rats at different levels of intake. Br J Nutr 54, 499-508.

63. Fatufe AA \& Rodehutscord M (2005) Growth, body composition, and marginal efficiency of methionine utilisation are affected by non-esssential amino acid nitrogen supplementation in male broiler chicken. Poult Sci 84, 1584-1592.

64. Peres H \& Oliva-Teles A (2008) Lysine requirement and efficiency of lysine utilisation in turbot (Scophthalmus maximus) juveniles. Aquaculture 275, 283-290.

65. Heger J, Krizova L, Sustale M, et al. (2008) Individual response of growing pigs to sulphur amino acid intake. J Anim Physiol Anim Nutr 92, 18-28. 